\title{
Pollution Status of Incomati River Estuary Based on Meiofauna Analyses (Free-living Nematodes) in Maputo, Mozambique
}

\author{
Soko Mthobisi Innocent ${ }^{*}$, Gyedu-Ababio Thomas \\ Inkomati-Usuthu Catchment Management Agency, Mbombela, South Africa \\ Email address: \\ sokom@iucma.co.za (Soko M. I.), thomasga@iucma.co.za (Gyedu-Ababio T.) \\ ${ }^{*}$ Corresponding author
}

\section{To cite this article:}

Soko Mthobisi Innocent, Gyedu-Ababio Thomas. Pollution Status of Incomati River Estuary Based on Meiofauna Analyses (Free-living Nematodes) in Maputo, Mozambique. Journal of Water Resources and Ocean Science. Vol. 8, No. 5, 2019, pp. 63-76.

doi: $10.11648 /$ j.wros.20190805.12

Received: September 23, 2019; Accepted: October 16, 2019; Published: October 23, 2019

\begin{abstract}
The Incomati Estuary, is located at Latitudes $25.430 \mathrm{~S}$ and $25.530 \mathrm{~S}$ and Longitudes $32.410 \mathrm{E}$ and $32.44^{\circ} \mathrm{E}$ and discharges in the northern part of Maputo Bay. Four sites E1 (Oligohaline Zone), E2 (Euhaline Zone), E3 (Mesohaline zone), and E4 (Polyhaline Zone) were selected following the salinity gradient of the Incomati River Estuary. Sediments samples were collected in these sites for both the analyses of meiofauna communities especially free-living nematodes and environmental variables such as Heavy Metal, Chlorophyll-a, Nitrates and Total phosphorus. Multivariate statistical analyses were used to analyses the data, and nematodes were identified into genus level. Higher concentration of Heavy Metals such as Cadmium, Cobalt, Chromium, Copper, Iron, Manganese, Nickel, Vanadium, Zinc, and Aluminium were found at site E2. Nematodes such as Terschellingia and Theristus were found to be suitable indicators in identifying pollution. The Maturity Index further indicated that sites E2 followed by E1 were the polluted sites in the estuary. Further studies confirming the findings of this study must be done in the Incomati River Estuary, and other studies must be done in the African Coast in order to understand free-living nematodes and close the gap in our monitoring strategies.
\end{abstract}

Keywords: Nematodes, Pollution, Sediments, Chlorophyll-a, Metals, Nitrates

\section{Introduction}

Estuarine areas are the most fruitful natural ecosystem because they provide important ecological functions and services such as habitat, shoreline protection, food for migratory and resident species, harbour and recreational purpose [1-3]. Because they are situated in the lower reaches of basin, estuarine receives large amount of nutrients and pollutant derived from anthropogenic activities such as agricultural and industrial effluents [3, 4]. The Incomati River Estuary is also susceptible to this kind of pollution from different activities such as mining, industries, agricultural and afforestation which exist in the upper catchment (Swaziland and South Africa) of the basin. Pollutants from these anthropogenic activities reaches the estuary either through seepage, effluents, and run-offs, and affects the estuarine ecosystem and other goods and services rendered by the estuary [5]. Nematodes have been used in assessing human and natural impacts in sediment because of their numerous advantages as biological indicators [6-9].

Numerous studies have used nematodes to assess soil pollution produced by heavy metal and nematodes were found to be dominant in finer sand less than $300 u$ m other than copepods which have been found to be dominant in

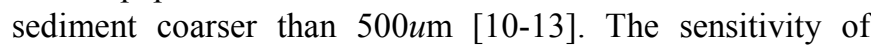
nematodes community to various kinds of anthropogenic disturbance have been emphasized by different studies $[8,14-$ 18]. Meiobenthic assemblage provides good information because of their ecological features which gives them several benefits over macrofauna communities as monitoring fauna [6-7, 19, 20-21]. The assessment of benthic assemblage's composition is a valuable tool for determining and describing environmental changes of estuarine and marine system [22].

As pollution indicators, meiofauna have been thoroughly 
studied in Bohai Sea [23-24], in the Huaghai Sea in china [23, 25-26] and in Changjiang Estuary areas [27-28]. In Tunisia and South Africa few studies of nematodes have been done [29-30], and only few studies used nematodes as pollution indicators [18, 31-32]. Several studies used Maturity Index to assess the impact caused by heavy metal, organic enrichment and eutrophication towards which nematodes responded positively [15, 33-38]. In a study conducted in the New York Bight [33], Maturity Index had a significant correlation with heavy metal concentration such as Chromium, Copper, Nickel, Lead, and Zinc. No studies in relation to meiofauna have been conducted in the Incomati
River Estuary to assess the pollution status of the Estuary. Thus, this study is the first to be done in this Estuary, and the main objective was to assess the pollution status of the Estuary using nematode assemblages as indicators.

\section{Materials and Methods}

\subsection{Study Area}

The Incomati Estuary, is located at Latitudes 25.430 S and 25.530 S and Longitudes $32.410 \mathrm{E}$ and $32.44^{\circ} \mathrm{E}$ (Figure 1), and discharges in the northern part of Maputo Bay.

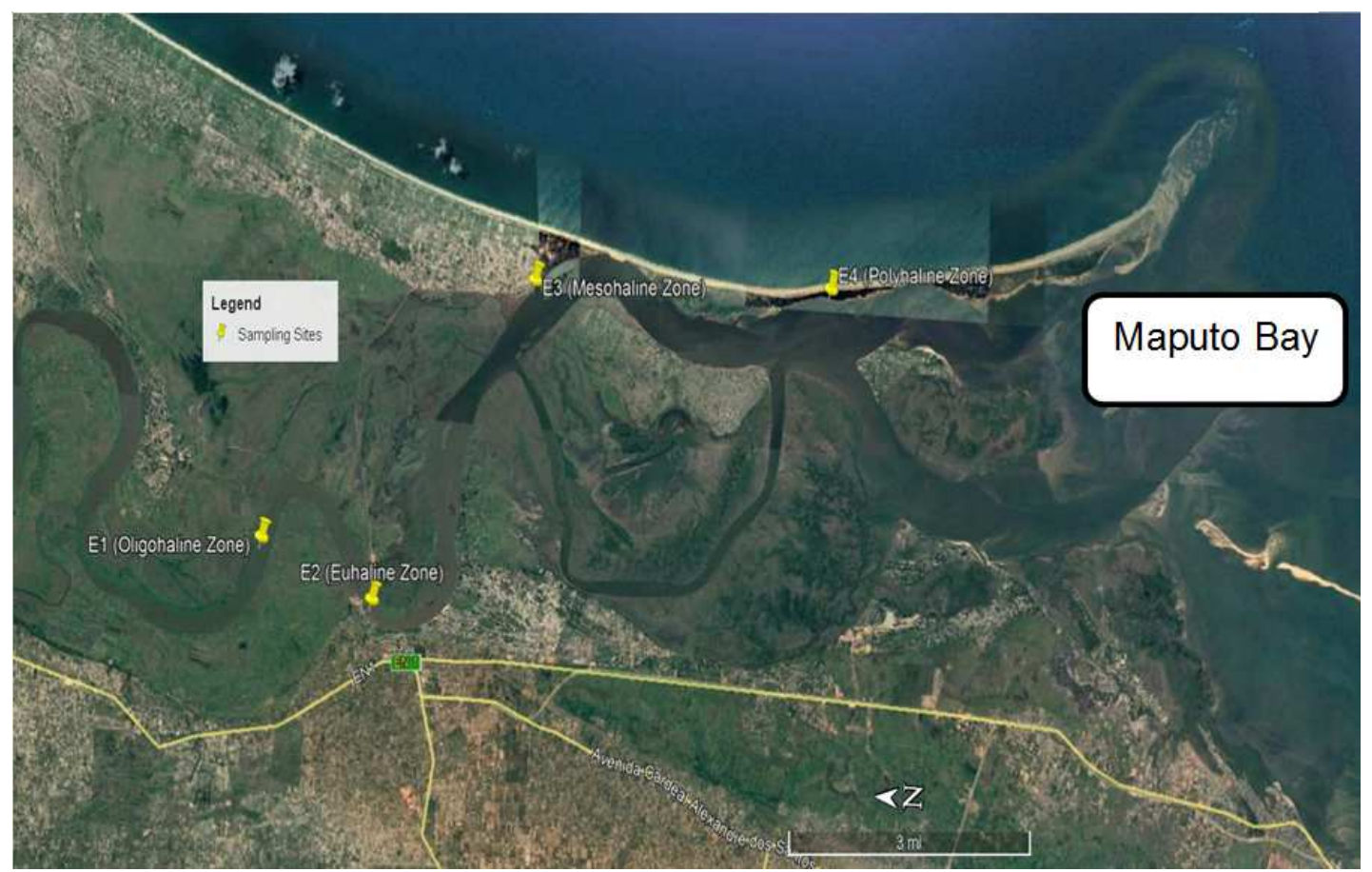

Figure 1. Map showing the monitoring sites in the study area.

Constructed dams in these rivers have changed the flow in the lower reaches, affecting the goods and services, therefore results in salt intruding in the inland [39-40]. The Incomati River Estuary is about 40-50 km long and meanders within the coastal plain. It is separated from the ocean by a narrow sand dune, a manifestation of the sluggish flow of the river. Four sites E1 (Oligohaline Zone), E2 (Euhaline Zone), E3 (Mesohaline zone), and E4 (Polyhaline Zone) were selected following the salinity gradient of the Incomati River Estuary for the purpose this study.

\subsection{Sample Collection and Analysis}

Sediments were taken from the estuary bi-monthly from June 2017 to April 2018 using a hand held perplex corer which had a diameter of $3.6 \mathrm{~cm}$ which penetrated a depth of $10 \mathrm{~cm}$. Three replicate samples were taken for meiofaunal and environmental variables analyses on each visit to the Estuary.

\subsection{Heavy Metal Analysis}

Heavy metals analysis was done using the method described [31]. Sediments samples were dried for $48 \mathrm{hrs}$ at $80^{\circ} \mathrm{C}$ in a petri-dishes. The dried samples were then crushed and about $2 \mathrm{~g}$ of each sample was taken into a glass beaker with $20 \mathrm{ml}$ Aqua Regia $\left(1: 3 \mathrm{HNO}_{3}\right.$ : $\left.\mathrm{HCL}\right)$ and allowed to react overnight. The mixture was heated to near dryness and allowed to cool, before $20 \mathrm{ml}$ of a $5 \mathrm{M} \mathrm{HNO}_{3}$ solution was added. The samples were left to react overnight and were then filtered using a Whatman No 41 filter paper. The filtrates were transferred to a $100 \mathrm{ml}$ volumetric flask and made up the mark with $0.5 \mathrm{M} \mathrm{HNO}_{3}$. Metal determinations of the solutions were perfomed on Shimadzu sequential plasma spectrometer (ICPS-1000II) using the calibration curve method. Concentration of the following metals: $\mathrm{Mn}, \mathrm{Al}, \mathrm{V}, \mathrm{Ti}, \mathrm{Cu}, \mathrm{Cr}$, $\mathrm{Pb}, \mathrm{Zn}, \mathrm{Cr}, \mathrm{Fe}, \mathrm{Cd}$, and $\mathrm{Co}$ were determined using this method.

\subsection{Sediment Particle Analysis}

Sediment particle size analysis was done using the method described [41]. A 30-g portion of the sediment from each site was washed with tap water and reweighed after 
drying. The samples were oven-dried at $60^{\circ} \mathrm{C}$ for $48 \mathrm{hrs}$. The dry samples were put on the topmost of a nest of sieves (with mesh size ranging from $0.002 \mu \mathrm{m}$ to $2 \mathrm{~mm}$ ) and sieved by a machine for 8 minutes. The fractions of each sieve were weighed. The median grain size, sorting values, mud composition and all the other sand fractions were determined using a computer programme, SANDX (SANDSTA.BAJ) by Olivetti (1984).

\subsection{Chlorophyll-a}

A $10 \mathrm{~g}$ of each sediment sample collected from the sites was placed in a $20 \mathrm{ml}$ screw cap vial. About $10 \mathrm{ml}$ of $90 \%$ acetone was then added in the vials containing sediments and swirled once gently [42]. The vials were placed in a $5^{\circ} \mathrm{C}$ incubator overnight. After incubation, the solution was filtered through a Whatman GF/C and placed in a screw cap test tube. The filtered solution was adjusted to $\mathrm{pH} 9$ using sodium hydroxide $(\mathrm{NaOH})$ as a buffering solution. This was done to reduce the interference of pheophytin with spectrophotometric analysis of chlorophyll. A spectrophotometry with a $1 \mathrm{~nm}$ spectral band width and optically matched $4 \mathrm{~cm}$ cuvettes was used. $3 \mathrm{ml}$ of extracts from each sample was poured in to the $4 \mathrm{~cm}$ cuvettes and the absorbance was measured at 664 and $750 \mathrm{~nm}$ before acidifying $\left(664_{\mathrm{b}}\right.$ and $\left.750_{\mathrm{b}}\right)$. This was done very quickly to prevent light from breaking down the chlorophyll. The absorbance was blanked at $664 \mathrm{~nm}$ using the $90 \%$ acetone solution with a second recorded at $750 \mathrm{~nm}$ to correct for primary pigments absorbance. After taking the initial measurements, a $0.1 \mathrm{ml}$ of $1 \mathrm{~N} \mathrm{HCl}$ was added directly to the cuvettes to estimate the amount of phaeopigments and the acid was allowed to react for 90 seconds and the absorbance was recorded at $665 \mathrm{~nm}$ and $750 \mathrm{~nm}\left(665_{\mathrm{a}}\right.$ and $\left.750_{\mathrm{a}}\right)$. The following equation was used to calculate Chlorophyll- $a$.

$$
\text { Chlorophyll }-a\left(\mathrm{mg} / \mathrm{m}^{3}\right)=\frac{26.7\left(E_{664 \mathrm{~b}}-E_{665 \mathrm{a}}\right) \times V_{(\text {extraction })}}{V_{(\text {sample })} \times L}
$$

Where:

b: Before acidification

a: After acidification

$$
\begin{aligned}
& \mathrm{E}_{664 \mathrm{~b}}=\left[\left(\mathrm{Abs}_{664 \mathrm{~b}(\text { sample }}\right)-\mathrm{Abs}_{664 \mathrm{~b}(\mathrm{blank})} \quad-\quad\left(\mathrm{Abs}_{750 \mathrm{~b}(\text { sample) }}\right.\right. \\
& \left.\mathrm{Abs}_{750 \mathrm{~b}(\mathrm{blank})}\right] \\
& \mathrm{E}_{665 \mathrm{a}}=\left[\left(\mathrm{Abs}_{665 \mathrm{a}(\text { sample }}\right)-\mathrm{Abs}_{665 \mathrm{a}(\mathrm{blank})} \quad-\quad\left(\mathrm{Abs}_{750 \mathrm{a}(\text { sample) }}\right.\right. \\
& \left.\mathrm{Abs}_{750 \mathrm{a}(\mathrm{blank})}\right] \\
& \mathrm{V}(\text { extraction): Volume of } 90 \% \text { acetone used in the } \\
& \operatorname{extraction}(\mathrm{ml}) \\
& \mathrm{V}(\text { sample) } \text { : Volume of water filtered } \\
& \text { L: Spectral path length }
\end{aligned}
$$

\subsection{Nitrates $\left(\mathrm{NO}_{3}\right)$}

A $25 \mathrm{ml}$ of $1 \mathrm{M} \mathrm{NaCl}$ solution was added to $1 \mathrm{~g}$ of undried sediments and shaken on Kotterman's mechanical shaker for 30 minutes [43]. The supernatant was then pass through Whatman's no. 1 filter paper, and only $3 \mathrm{ml}$ of the filtrate was used for analysis in a test tube. A buffer solution $(2 \mathrm{ml})$ was added to the filtrate and shaken for 10 minutes. Standard solutions were then made in series: $0 ; 0.5 ; 1.0 ; 1.5 ; 2.0$ and made up to a volume of $100 \mathrm{ml}$ with distilled water. A $1 \mathrm{ml}$ sulphanilimide was added to $1 \mathrm{ml}$ of the sample followed by $1 \mathrm{ml}$ solution of diamine-hydrochloride. The mixture stayed for 5 minutes and the nutrient concentrations were then read on a Pye Unicam Spectrophotometer SP 1800 at $540 \mathrm{~nm}$.

\subsection{Total Phosphorus (TP)}

Sediment was dried in an oven at $80^{\circ} \mathrm{C}$, and sieved through a 4um sieve [44]. $1 \mathrm{~g}$ of the sieve sieved sample was heated in a $50 \mathrm{ml}$ conical flask on a digestion rack in a $4 \mathrm{ml}$ mixed acid digester for 2 hrs. The mixture was cooled down, and then diluted to $50 \mathrm{ml}$ with distilled water. Ten $\mathrm{ml}$ colour reagent (1.06 g ascorbic acid, $1.2 \mathrm{~g}$ ammonium molybdate $\left(\left(\mathrm{NH}_{4}\right)_{6} \mathrm{Mo}_{7} \mathrm{O}_{24} \cdot 4 \mathrm{H}_{2} \mathrm{O}\right)$ and $27 \mathrm{mg}$ of potassium antimony oxide tartrate in $180 \mathrm{ml}$ distilled water) were added to $1 \mathrm{ml}$ of the solution/mixture. This was followed by the addition of $9.5 \mathrm{ml}$ concentrated $\mathrm{H}_{2} \mathrm{SO}_{4}$. The mixture was left to stand for an hour for the colour to develop. Standard series, 0, 0.5, 1.0, $1.5,2.0,2.5$, was made and observed at $690 \mathrm{~nm}$ using a spectrophotometer. A phosphorus standard curve was used to determine the total phosphorus content in the sediment sample.

\subsection{Meiofauna Field Collection}

A $6 \% \mathrm{MgCl}_{2}$ was used to rinse the inner diameter of the corer as to allow meiofauna to relax during sediment sampling. Sediment samples were taken from the four sites selected in the salinity gradient of the Incomati River Estuary. In each site, a duplicate of sediment samples was taken using a $1 \mathrm{~m}$ long PVC corer with an inner diameter of $3.6 \mathrm{~cm}$, corresponding to a surface area of $10 \mathrm{~cm}^{2}$.

\subsubsection{Meiofauna Laboratory Analysis}

In the laboratory, sediment samples were transferred to centrifugal bottles and weighed. A sucrose solution of $589 \mathrm{~g}$ prepared in a $1 \mathrm{~L}$ bottle was added in the centrifugal bottles containing sediments to separate meiofauna from the sediments [45-47]. The sediment samples were centrifuged at $35000 \mathrm{rmp}$ for 5 minutes and the supernatant were decanted to another jar. After the supernatant was decanted, the bottles were weighed, and an amount of sucrose solution was added again. The samples were centrifuged for another 5 minutes. The final supernatant was decatant in to the same jar and sieve on a mesh aperture of $1 \mathrm{~mm}$ followed by a sieve with a mesh aperture of 63um. Detritus and macrofauna were retained in the upper sieve were discarded, and meiofauna were retained by the lower sieve. Meiofauna were then collected in 5\% formalin with Rose Bengal for staining and easier identification.

\subsubsection{Nematodes Counting and Identification}

Nematodes were then counted under a stereo microscope at 40x magnification using a counting petri-dish or a sorting tray [48]. They were then place in to solution of 5 parts glycerine, 5 parts ethanol and 90 parts distilled water. Finally, nematodes were mounted on a glass slides and identify to 
genus level using the pictorial keys of [49]. The functional feeding groups designated [50] was used to investigate the trophic composition of nematodes assemblages.

\subsection{Statistical Analyses}

\subsubsection{Environmental Variables}

To find the pattern of multidimensional data of the environmental variables, a Principal Component Analyses (PCA) was performed to reduce the number of dimensions with a minimal loss of information. Environmental variables and each of the granulometric classes were transformed in to a square root. The calculation of environmental variables similarity matrix was based on Euclidean distance. A oneway ANOSIM was used to determine the significant difference between sites based on their environmental variables.

\subsubsection{Meiofauna Assemblages}

To investigate the trophic composition of nematodes assemblage, the features of buccal cavity morphology was followed [50]. According to this approach, four groups of feeders were defined: Selective deposit feeders (1A), nonselective deposit feeders (1B), epigrowth feeders (2A), and predator or omnivores (2B). The Index of Trophic Diversity was calculated as $\mathrm{ITD}=\Sigma \theta^{2}$ where 0 was the density contribution of each trophic diversity [19]. The ITD was used to compare the sites in terms of sediment contamination by heavy metals. To analyse nematodes life strategy, the Maturity Index was used [34], The Maturity Index formular

$$
\mathrm{MI}=\sum_{i=1}^{n} \mathrm{v}(\mathrm{i}) \cdot \mathrm{f}(\mathrm{i})
$$

was used to calculate the weighted average of the individual colonizer-persisters (c-p) values. The following symbols in the formular: v(i) represented the c-p value of the taxon, then $i$ and $f(i)$ was the frequency of that taxon. To determine the ecological quality status of the Incomati River Estuary the Maturity Index thresholds proposed by Moreno et al. 2011 were used to analyse the results.

A PRIMER VERSION 6 software was used to perform a univariate and multivariate analyses for both meiofauna and nematodes data. A PERMANOVA analyses using a BrayCurtis similarity matrix to test the notion that meiofauna and nematodes community changes over a space and time with sites and month as fixed factors. Nematode groups were square root transformed to scale down their densities and to increase the importance of less abundance group analysis. A Redundancy Triplot analyses (XLSTATS software) was used to determine the relationships of nematodes and environmental factors. A non-parametric correlation spearman analyses were used to test the relationship between nematodes and environmental factors. The one-way ANONISM permutation test was further used to test the difference between monthly sampling, and sites for the relative abundance of the four feeding types. A K-dominance curve was plotted for the comparison of species composition at the sampling sites. A Distance Linear Model (DistLM) was used to determine the relationship between environmental variables and the structure of nematodes community [51-52]. The DistLM routine was based on the AIC model selection criterion using the step-wise selection procedure [53]. The above analyses were conducted using PRIMER 6.0 which is a multivariate statistical package developed by Plymouth Marine Laboratory [54].

\section{Results}

\subsection{Sediments}

Variation of sediment particle sizes was found in the four sites sampled in the Incomati river estuary and the percentage of fine sand particle was higher towards fresh water where deposition was higher. Site E1 was characterised mostly by fine sand with $46.32 \%$, followed by granules $(>2.0 \mathrm{~mm})$, and mud and fine sand $(<212$ um) with $21.31 \%$ and $19.6 \%$ respectively. Site E2 was mostly characterised by granules sand $(>2.0 \mathrm{~mm})$ with $32.28 \%$, followed by medium grain size, and mud and fine sand with $30.48 \%$ and $14.7 \%$ respectively. At site E3, variation of particles sites was found at this site, but the most dominant particle size was coarse to very coarse sand (600um) with $35.47 \%$, followed by granules $(>2.0 \mathrm{~mm})$, very coarse sand $(1.4 \mathrm{~mm})$ with $22.64 \%$ and $16.91 \%$ respectively. Fine and medium sand particles (212-355um) contributed $12.56 \%$ of sediment particle sizes. Site E4 was mostly characterised by coarse to very coarse sand particles with $47.79 \%$. A one-way ANOVA indicated that there was no significant difference $(\mathrm{p}>0.05)$ of sediments particle size between the sites sampled.

\subsection{Heavy Metals}

Ten metal concentrations (Cadmium, Cobalt, Chromium, Copper, Iron, Manganese, Nickel, Vanadium, Zinc, and Aluminium) were found (Table 1) in the estuary. The highest concentration of heavy metals was found at sites E2 (Euhaline Zone) and E1 (Oligohaline Zone). The PERMANOVA results indicated that there was a significant difference $(p<0.05)$ between sites sampled, but significant difference $(p>0.05)$ did not exist between months sampling which indicated that the concentration of metals changes spatial, but not temporal.

Table 1. Environment factors analyse in the Incomati River Estuary from June 2017 to April 2018.

\begin{tabular}{|c|c|c|c|c|c|c|c|c|c|c|c|c|}
\hline \multirow{2}{*}{$\begin{array}{l}\text { Environmental } \\
\text { Factors }\end{array}$} & \multicolumn{6}{|l|}{ E1 } & \multicolumn{6}{|l|}{ E2 } \\
\hline & Jun-17 & Aug-17 & Oct-17 & Dec-17 & Feb-18 & Apr-18 & Jun-17 & Aug-17 & Oct-17 & Dec-17 & Feb-18 & Apr-18 \\
\hline $\mathrm{Cd}(\mathrm{ppm})$ & 0.27 & 0.12 & 0.1 & 0.1 & 0.1 & 0.1 & 0.3 & 0.29 & 0.13 & 0.12 & 0.09 & 0.09 \\
\hline Co (ppm) & 6 & 2.7 & 2.8 & 2.7 & 2.7 & 2.7 & 8.6 & 8.7 & 1.9 & 1.8 & 0.82 & 1.5 \\
\hline $\mathrm{Cr}(\mathrm{ppm})$ & 22 & 12 & 9.4 & 6.1 & 6.1 & 6.1 & 20 & 30 & 11 & 14 & 8.3 & 6.2 \\
\hline
\end{tabular}




\begin{tabular}{|c|c|c|c|c|c|c|c|c|c|c|c|c|}
\hline \multirow{2}{*}{$\begin{array}{l}\text { Environmental } \\
\text { Factors }\end{array}$} & \multicolumn{6}{|l|}{ E1 } & \multicolumn{6}{|l|}{ E2 } \\
\hline & Jun-17 & Aug-17 & Oct-17 & Dec-17 & Feb-18 & Apr-18 & Jun-17 & Aug-17 & Oct-17 & Dec-17 & Feb-18 & Apr-18 \\
\hline $\mathrm{Cu}(\mathrm{ppm})$ & 9.5 & 5.6 & 5 & 3.8 & 3.8 & 3.8 & 12 & 13 & 6.5 & 6.3 & 4.4 & 4.9 \\
\hline $\mathrm{Fe}(\mathrm{ppm})$ & 9549 & 4667 & 4191 & 2574 & 2574 & 2574 & 20595 & 21130 & 3938 & 3892 & 1951 & 3245 \\
\hline Mn (ppm) & 242 & 164 & 132 & 68 & 68 & 68 & 320 & 391 & 116 & 101 & 55 & 181 \\
\hline $\mathrm{Ni}(\mathrm{ppm})$ & 18 & 7.3 & 6.7 & 6.1 & 6.1 & 6.1 & 22 & 24 & 7.6 & 8 & 4.4 & 5.8 \\
\hline V (ppm) & 16 & 6.8 & 6.1 & 4.1 & 4.1 & 4.1 & 27 & 27 & 6 & 6.1 & 2.9 & 4.8 \\
\hline $\mathrm{Zn}(\mathrm{ppm})$ & 15 & 18 & 7.1 & 14 & 14 & 14 & 24 & 25 & 5.9 & 6.1 & 3.6 & 11 \\
\hline $\mathrm{Al}(\mathrm{ppm})$ & 11648 & 4974 & 3898 & 2764 & 2764 & 2764 & 16945 & 15945 & 4415 & 4150 & 2236 & 3921 \\
\hline TP & 110 & 79 & 35 & 27 & 27 & 27 & 273 & 300 & 68 & 68 & 36 & 59 \\
\hline $\mathrm{NO}_{3}(\mathrm{mg} / \mathrm{l})$ & 0.05 & 0.05 & 0.05 & 0.05 & 0.05 & 0.05 & 0.01 & 0.01 & 0.01 & 0.01 & 0.01 & 0.01 \\
\hline Chl-a $\left(\mathrm{mg} / \mathrm{m}^{3}\right)$ & 0.8 & 0.6 & 1.2 & 0.9 & 0.7 & 1.5 & 0.6 & 1.6 & 0.9 & 0.5 & 0.9 & 0.7 \\
\hline
\end{tabular}

Table 1. Continued.

\begin{tabular}{|c|c|c|c|c|c|c|c|c|c|c|c|c|}
\hline \multirow{2}{*}{$\begin{array}{l}\text { Environmental } \\
\text { Factors }\end{array}$} & \multicolumn{6}{|l|}{ E3 } & \multicolumn{6}{|l|}{ E4 } \\
\hline & Jun-17 & Aug-17 & Oct-17 & Dec-17 & Feb-18 & Apr-18 & Jun-17 & Aug-17 & Oct-17 & Dec-17 & Feb-18 & Apr-18 \\
\hline $\mathrm{Cd}$ (ppm) & 0.09 & 0.09 & 0.09 & 0.09 & 0.17 & 0.1 & 0.09 & 0.09 & 0.09 & 0.09 & 0.09 & 0.09 \\
\hline $\mathrm{Co}$ (ppm) & 1.3 & 1.3 & 1.3 & 0.95 & 3.6 & 1.2 & 0.34 & 0.77 & 0.62 & 0.38 & 0.52 & 0.36 \\
\hline $\mathrm{Cr}$ (ppm) & 17 & 17 & 17 & 16 & 44 & 9.3 & 6 & 13 & 7.6 & 6.3 & 7.2 & 7.1 \\
\hline $\mathrm{Cu}(\mathrm{ppm})$ & 3.8 & 3.8 & 3.8 & 3.1 & 7.2 & 4.5 & 3.8 & 5.1 & 3.6 & 3.5 & 4 & 4.6 \\
\hline $\mathrm{Fe}(\mathrm{ppm})$ & 1952 & 1952 & 1952 & 1799 & 6336 & 2676 & 1648 & 1531 & 1761 & 1472 & 1495 & 1315 \\
\hline Mn (ppm) & 44 & 44 & 44 & 45 & 101 & 51 & 26 & 172 & 50 & 33 & 41 & 36 \\
\hline $\mathrm{Ni}(\mathrm{ppm})$ & 2.3 & 2.3 & 2.3 & 2.1 & 8.3 & 3.4 & 2.1 & 7.5 & 3 & 2.8 & 2.9 & 3.1 \\
\hline $\mathrm{V}(\mathrm{ppm})$ & 2.9 & 2.9 & 2.9 & 2.9 & 10 & 4.1 & 1.1 & 1.1 & 1.8 & 1.3 & 2 & 1.3 \\
\hline $\mathrm{Zn}(\mathrm{ppm})$ & 4 & 4 & 4 & 5.3 & 14 & 9.2 & 13 & 25 & 2.7 & 3.7 & 3.8 & 5.1 \\
\hline $\mathrm{Al}(\mathrm{ppm})$ & 1328 & 1328 & 1328 & 1316 & 5976 & 2312 & 748 & 551 & 1101 & 1003 & 1150 & 872 \\
\hline TP & 34 & 34 & 34 & 34 & 83 & 46 & 25 & 15 & 30 & 24 & 25 & 24 \\
\hline $\mathrm{NO}_{3}(\mathrm{mg} / \mathrm{l})$ & 0.07 & 0.07 & 0.07 & 0.07 & 0.1 & 0.1 & 0.14 & 0.14 & 0.14 & 0.1 & 0.06 & 0.1 \\
\hline Chl-a $\left(\mathrm{mg} / \mathrm{m}^{3}\right)$ & 0.8 & 0.7 & 4 & 4.3 & 4.6 & 4.9 & 0.04 & 2.2 & 1.8 & 0.7 & 2 & 0.7 \\
\hline
\end{tabular}

\subsection{Chlorophyll-a}

The highest Chlorophyll- $a$ concentration from sediments was found at site E3 with mean concentration value of 3.2 $\mathrm{mg} / \mathrm{m}^{3}$ followed by site $\mathrm{E} 4$ with a mean concentration of 1.24 $\mathrm{mg} / \mathrm{m}^{3}$. There was a significant difference $(\mathrm{p}<0.05)$ between the sites pertaining the chlorophyll-a concentration between the sites.

\subsection{Nitrates $\left(\mathrm{NO}_{3}\right)$}

A variation of nitrates concentration was observed at site E3 with a range of $0.07(\mathrm{mg} / \mathrm{l})$ to $0.1(\mathrm{mg} / \mathrm{l})$ and a mean concentration of $0.08(\mathrm{mg} / \mathrm{l})$ (Table 1). Similarly, at site E4 a variation of nitrate concentration was observed with a range of $0.06(\mathrm{mg} / \mathrm{l})$ to $0.14(\mathrm{mg} / \mathrm{l})$, with a mean concentration value of $0.11(\mathrm{mg} / \mathrm{l})$. Significant difference $(\mathrm{p}<0.05)$ was observed between the sites sampled pertaining to nitrates concentration.

\subsection{Total Phosphorus}

The highest concentration of total phosphate was observed as site E2 with a mean value of 134 (ppm) (Table 1). Site E1 had the second highest concentration of total phosphate with a mean value of 50.8 (ppm). Sites E3 and E4 had a mean concentration of total phosphate of 44.2 (ppm) and 27 (ppm) respectively. There was a significant difference $(\mathrm{p}<0.05)$ of total phosphate between the sites.

\subsection{Relationship Between Environmental Factors}

The first two PCA axes were accounted for a total of $92.6 \%$ of the total variation with the PCA1 and PCA2 accounted for $70 \%$ and $22.6 \%$ respectively (Figure 2 ). The high percentage of variations was also seen in the eigenvectors which gave consistent large values for the environmental factors except for Nitrates, Gravel, Fine Medium Sand, Zinc, Fine Sand and Chromium on the PCA1 axis. The PCA shows the eigenvector numbers graphically, with most environmental factors increasing towards site E2 (Euhaline Zone). In contrast, Nitrates, Gravel, Fine Medium Sand, Zinc, Fine Sand and Chromium all had the large eigenvector on the PCA2 axis, thus their vectors increased on the PCA2. Fine Sand, Fine Medium Sand and Zinc increased on the direction of the Oligohaline Zone at site E1. Nitrates and Coarse Very Coarse sand increased towards the Polyhaline Zone (E4) and Chlorophyll-a and Very Coarse Sand increased towards the Mesohaline Zone (E3). The PCA analyses lastly indicated the separation of sampling sites or zones within the Estuary and the ANOSIM formally confirms this with an overall ANOSIM $\mathrm{R}$ of 0.501 , reflecting the pairwise $\mathrm{R}$ values of the sites. 


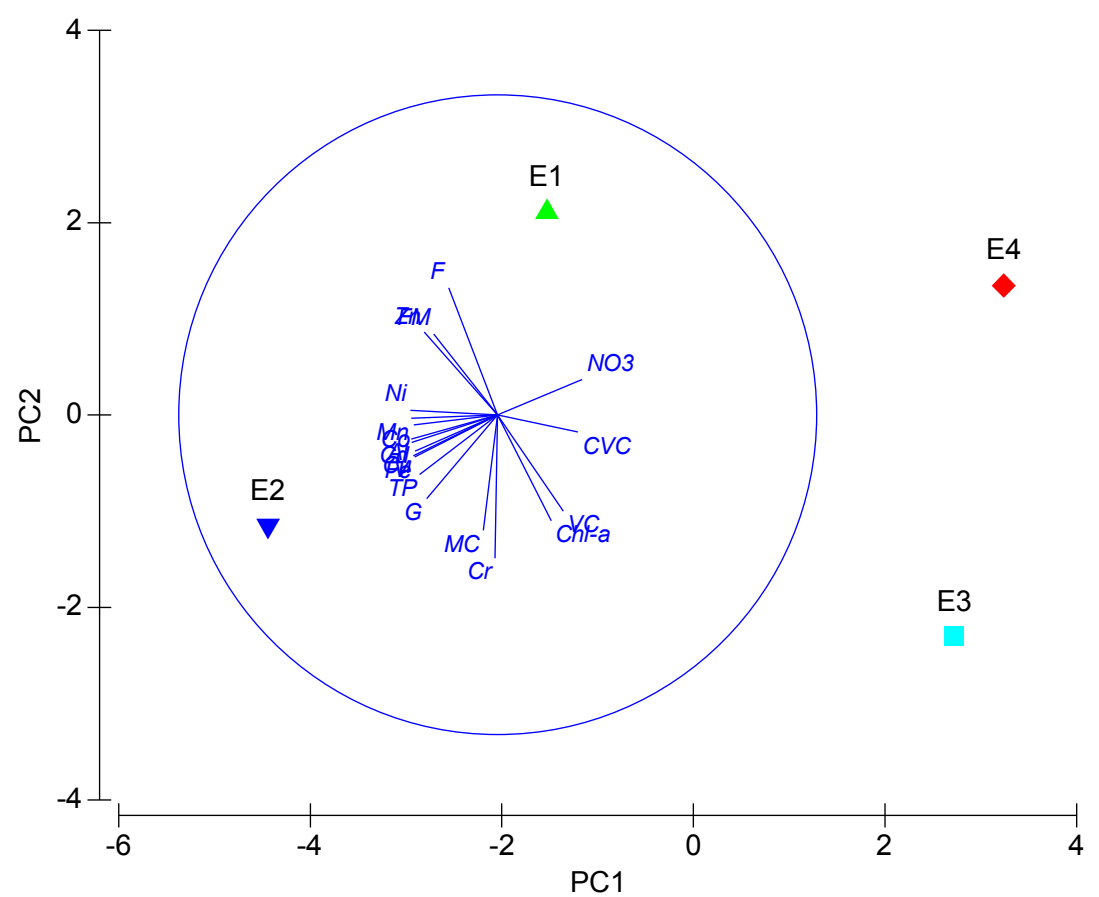

Figure 2. Principal Component Analyses of normalized environmental variables showing the environmental gradients along the Incomati River Estuary.

\subsection{Meiofauna Assemblages}

Meiofauna density and their composition followed a clear pattern along the estuarine salinity gradient in the Incomati River Estuary. Nine meiofaunal taxa (Nematoda, Copepoda Turbellaria, Amphipoda, Polychaeta, Kinorhyncha, Oligochaeta, Gastrotricha, Ostracoda) and other insecta were found in the Incomati River Estuary (Table 2). A PERMANOVA analyses show a significant difference $\mathrm{p}<0.05$ between the months and sites sampled. The density of meiofauna were found to decrease from Polyhaline Zone (site E4) to Oligohaline Zone (site E1) with meiofauna density of 211 individuals $/ 10 \mathrm{~cm}^{2}$ and 70 individuals $/ 10 \mathrm{~cm}^{2}$ respectively.

Table 2. Meiofauna community identified along a salinity gradient in the Incomati River Estuary from June 2017 to April 2018.

\begin{tabular}{|c|c|c|c|c|c|c|c|c|c|c|c|c|}
\hline \multirow{4}{*}{ MEIOFAUNA } & \multicolumn{6}{|l|}{ E1 } & \multicolumn{6}{|l|}{ E2 } \\
\hline & \multicolumn{12}{|c|}{ Salinity Range } \\
\hline & \multicolumn{6}{|c|}{ 0-3NST } & \multicolumn{6}{|l|}{ 3-5NST } \\
\hline & Jun-17 & Aug-17 & Oct-17 & Dec-17 & Feb-18 & Apr-18 & Jun-17 & Aug-17 & Oct-17 & Dec-17 & Feb-18 & Apr-18 \\
\hline Nematoda & 61 & 110 & 100 & 150 & 200 & 100 & 70 & 160 & 150 & 123 & 157 & 141 \\
\hline Copepoda & 7 & 2 & 2 & 1 & 0 & 0 & 0 & 11 & 12 & 6 & 0 & 8 \\
\hline Turbellaria & 3 & 9 & 6 & 7 & 1 & 6 & 0 & 3 & 3 & 6 & 0 & 0 \\
\hline Amphipoda & 0 & 2 & 0 & 6 & 1 & 1 & 2 & 0 & 0 & 1 & 9 & 3 \\
\hline Halacarida & 0 & 0 & 0 & 0 & 0 & 0 & 0 & 0 & 0 & 0 & 0 & 0 \\
\hline Polychaeta & 2 & 1 & 6 & 4 & 0 & 4 & 4 & 2 & 11 & 12 & 18 & 6 \\
\hline Kinorhyncha & 0 & 0 & 0 & 2 & 2 & 0 & 3 & 2 & 1 & 0 & 1 & 2 \\
\hline Oligochaeta & 2 & 4 & 0 & 3 & 5 & 0 & 1 & 7 & 8 & 0 & 0 & 0 \\
\hline Gastrotricha & 0 & 0 & 5 & 0 & 3 & 0 & 0 & 3 & 7 & 1 & 0 & 0 \\
\hline Ostracoda & 2 & 0 & 6 & 13 & 0 & 0 & 8 & 9 & 0 & 9 & 2 & 4 \\
\hline Ciliophora & 0 & 0 & 0 & 0 & 0 & 0 & 0 & 0 & 0 & 0 & 0 & 0 \\
\hline Cladocera & 0 & 0 & 0 & 0 & 0 & 0 & 0 & 0 & 0 & 0 & 0 & 0 \\
\hline Insecta & 3 & 0 & 7 & 0 & 0 & 0 & 0 & 0 & 0 & 5 & 0 & 0 \\
\hline
\end{tabular}

Table 2. Continued.

\begin{tabular}{|c|c|c|c|c|c|c|c|c|c|c|c|c|}
\hline \multirow{4}{*}{ MEIOFAUNA } & \multicolumn{6}{|l|}{ E3 } & \multicolumn{6}{|l|}{$\overline{\text { E4 }}$} \\
\hline & \multicolumn{12}{|c|}{ Salinity Range } \\
\hline & \multicolumn{6}{|c|}{$5-18 N S T$} & \multicolumn{6}{|c|}{ 18-26NST } \\
\hline & Jun-17 & Aug-17 & Oct-17 & Dec-17 & Feb-18 & Apr-18 & Jun-17 & Aug-17 & Oct-17 & Dec-17 & Feb-18 & Apr-18 \\
\hline Nematoda & 200 & 200 & 350 & 680 & 252 & 180 & 321 & 250 & 400 & 890 & 422 & 322 \\
\hline Copepoda & 8 & 10 & 7 & 32 & 21 & 1 & 7 & 3 & 16 & 13 & 10 & 0 \\
\hline Turbellaria & 5 & 0 & 2 & 0 & 0 & 4 & 0 & 3 & 9 & 6 & 8 & 3 \\
\hline Amphipoda & 6 & 2 & 2 & 5 & 0 & 1 & 0 & 0 & 3 & 0 & 0 & 0 \\
\hline Halacarida & 0 & 0 & 0 & 0 & 0 & 0 & 0 & 0 & 0 & 0 & 0 & 0 \\
\hline Polychaeta & 0 & 0 & 2 & 0 & 0 & 0 & 0 & 0 & 0 & 2 & 0 & 0 \\
\hline
\end{tabular}




\begin{tabular}{|c|c|c|c|c|c|c|c|c|c|c|c|c|}
\hline \multirow{4}{*}{ MEIOFAUNA } & \multicolumn{6}{|l|}{ E3 } & \multicolumn{6}{|l|}{ E4 } \\
\hline & \multicolumn{12}{|c|}{ Salinity Range } \\
\hline & \multicolumn{6}{|c|}{ 5-18NST } & \multicolumn{6}{|c|}{ 18-26NST } \\
\hline & Jun-17 & Aug-17 & Oct-17 & Dec-17 & Feb-18 & Apr-18 & Jun-17 & Aug-17 & Oct-17 & Dec-17 & Feb-18 & Apr-18 \\
\hline Kinorhyncha & 2 & 0 & 0 & 0 & 2 & 1 & 7 & 0 & 2 & 2 & 4 & 3 \\
\hline Oligochaeta & 0 & 0 & 0 & 2 & 0 & 0 & 0 & 0 & 0 & 0 & 0 & 0 \\
\hline Gastrotricha & 4 & 5 & 0 & 0 & 3 & 0 & 4 & 2 & 0 & 3 & 0 & 0 \\
\hline Ostracoda & 3 & 11 & 21 & 8 & 8 & 9 & 1 & 2 & 5 & 19 & 6 & 4 \\
\hline Ciliophora & 0 & 0 & 0 & 0 & 0 & 0 & 0 & 0 & 0 & 0 & 0 & 0 \\
\hline Cladocera & 0 & 0 & 0 & 0 & 0 & 0 & 0 & 0 & 0 & 0 & 0 & 0 \\
\hline Insecta & 5 & 0 & 0 & 1 & 3 & 0 & 0 & 3 & 0 & 0 & 2 & 0 \\
\hline
\end{tabular}

In all sites nematodes were the most dominant meiofauna taxa with a density of 6311 individual $/ 10 \mathrm{~cm}^{2}$ and contributed about $92 \%$ of the total meiofaunal abundance. Copepods were found to be the second dominant meiofaunal group in the estuary. They had a density of 177 individuals $/ 10 \mathrm{~cm}^{2}$ contributing $2.7 \%$ of the total meiofauna group. Ostracoda and Turbellaria contributed $2 \%$ and $0.9 \%$ of the total meiofauna group respectively.

\subsubsection{Nematodes Density}

A total of 5989 nematodes were found with variation of density between the months sampled. The highest density of nematodes at sites E1 (200 individual $\left./ 10 \mathrm{~cm}^{2}\right)$, E2 (160 individual $\left./ 10 \mathrm{~cm}^{2}\right), \mathrm{E} 3$ (680 individual $\left./ 10 \mathrm{~cm}^{2}\right)$, and E4 (890 individual $/ 10 \mathrm{~cm}^{2}$ ) were found in the months of February 2018, August 2017 and December 2017 respectively (Table 3).

Nematode density decreased towards site E1 which was situated in the Oligohaline zone. A significant difference $(p<0.05)$ of nematodes density between the sites sampled during the study period was observed.

\subsubsection{Nematode Diversity}

A total of 2363 nematode were identified using a compound microscope, and a total of 39 nematode genera were found in the Incomati River Estuary (Table 4). The highest diversity of nematode was found at site E4 (Polyhaline zone) and the lowest was found at sites E2 (Euhaline Zone) and E1 (Oligohaline Zone). The diversity of nematodes at site E1 (Oligohaline Zone) ranged from 4 to 13 and the genus dominated this site was Haliplectus which dominated the community with $41 \%$, followed by Axonolaimus with $13.2 \%$. At site E2 (Euhaline Zone), the number of nematodes genera ranged from 4 to 12 , and nematode genera dominated this site were Terschellingia with $47.5 \%$, followed by Theristus with $20.8 \%$ of the total community. Other nematode genera that dominated the community at site E2 were Axonolaimus, Sabatiera, Daptonema, and Parodontophora. At sites E3 and E4, nematode genera ranged from 11 to 18 and 13 to 21 respectively.

Table 3. Mean monthly density (Individuals $/ 10 \mathrm{~cm}^{2}$ ) at the study sites in the Incomati River Estuary from June 2017 to April 2018.

\begin{tabular}{lllll}
\hline Site Names & E1 & E2 & E3 & E4 \\
\hline June 2017 & 61 & 70 & 200 & 321 \\
August 2017 & 110 & 160 & 200 & 250 \\
October 2017 & 100 & 150 & 350 & 400 \\
December 2017 & 150 & 123 & 680 & 890 \\
February 2018 & 200 & 157 & 252 & 422 \\
April 2018 & 100 & 141 & 180 & 322 \\
Total & 721 & 801 & 1862 & 2605 \\
MEAN (SD) & 120.2 & 133.5 & 310.3 & 434.2 \\
& $(48.3)$ & $(33.8)$ & $(191.3)$ & $(231.7)$ \\
\hline
\end{tabular}

Table 4. Feeding types, c-p values, salinity ranged, and Nematodes Genera identified in the Incomati River Estuary from June 2017 to April 2018.

\begin{tabular}{|c|c|c|c|c|c|c|c|c|c|c|c|c|c|c|}
\hline \multirow{4}{*}{$\begin{array}{l}\text { NEMATODE } \\
\text { GENUS }\end{array}$} & \multirow{4}{*}{$\begin{array}{l}\text { c-p } \\
\text { values }\end{array}$} & \multirow{4}{*}{$\begin{array}{l}\text { Feeding } \\
\text { types }\end{array}$} & \multirow{2}{*}{\multicolumn{6}{|c|}{$\begin{array}{l}\text { E1 } \\
\text { Salinity range amongst the sites }\end{array}$}} & \multirow{2}{*}{\multicolumn{6}{|c|}{ E2 }} \\
\hline & & & & & & & & & & & & & & \\
\hline & & & \multicolumn{6}{|c|}{ 0-3NST } & \multicolumn{6}{|c|}{ 3-5NST } \\
\hline & & & $\begin{array}{l}\text { Jun- } \\
17 \\
\end{array}$ & $\begin{array}{l}\text { Aug- } \\
17\end{array}$ & $\begin{array}{l}\text { Oct- } \\
17 \\
\end{array}$ & $\begin{array}{l}\text { Dec- } \\
17 \\
\end{array}$ & $\begin{array}{l}\text { Feb- } \\
18 \\
\end{array}$ & $\begin{array}{l}\text { Apr- } \\
18 \\
\end{array}$ & $\begin{array}{l}\text { Jun- } \\
17 \\
\end{array}$ & $\begin{array}{l}\text { Aug- } \\
17\end{array}$ & $\begin{array}{l}\text { Oct- } \\
17 \\
\end{array}$ & $\begin{array}{l}\text { Dec- } \\
17 \\
\end{array}$ & $\begin{array}{l}\text { Feb- } \\
18 \\
\end{array}$ & $\begin{array}{l}\text { Apr- } \\
18 \\
\end{array}$ \\
\hline Adoncholaimus & 3 & $2 \mathrm{~B}$ & 13 & 12 & 15 & 3 & 0 & 0 & 0 & 0 & 1 & 0 & 0 & 0 \\
\hline Aegialoalaimus & 4 & $1 \mathrm{~A}$ & 3 & 0 & 0 & 4 & 2 & 0 & 0 & 0 & 2 & 0 & 0 & 0 \\
\hline Anoplostoma & 2 & $1 \mathrm{~B}$ & 10 & 15 & 0 & 9 & 13 & 11 & 0 & 0 & 2 & 0 & 0 & 0 \\
\hline Axonolaimus & 2 & $1 \mathrm{~B}$ & 3 & 15 & 16 & 12 & 3 & 26 & 0 & 10 & 9 & 10 & 10 & 20 \\
\hline Batylaiumus & 2 & $1 \mathrm{~B}$ & 0 & 0 & 0 & 0 & 0 & 0 & 0 & 0 & 0 & 0 & 0 & 0 \\
\hline Camacolaimus & 3 & $2 \mathrm{~A}$ & 0 & 0 & 0 & 0 & 0 & 8 & 3 & 2 & 0 & 1 & 0 & 0 \\
\hline Cephalainticoma & 2 & $2 \mathrm{~A}$ & 0 & 0 & 0 & 0 & 0 & 0 & 0 & 0 & 0 & 0 & 0 & 0 \\
\hline Daptonema & 3 & 1B & 0 & 3 & 1 & 2 & 0 & 0 & 1 & 1 & 1 & 10 & 3 & 0 \\
\hline Dichromadora & 2 & $2 \mathrm{~A}$ & 0 & 0 & 0 & 0 & 0 & 0 & 0 & 0 & 0 & 0 & 0 & 0 \\
\hline Dolicholaimus & 2 & $2 \mathrm{~B}$ & 0 & 0 & 0 & 0 & 0 & 0 & 0 & 0 & 0 & 0 & 0 & 0 \\
\hline Enoplus & 5 & $2 \mathrm{~B}$ & 0 & 0 & 0 & 0 & 0 & 0 & 0 & 0 & 0 & 2 & 0 & 0 \\
\hline Filoncholaimus & 4 & $2 \mathrm{~B}$ & 0 & 0 & 0 & 0 & 0 & 0 & 0 & 0 & 0 & 4 & 0 & 0 \\
\hline Halalaimus & 4 & $1 \mathrm{~A}$ & 0 & 0 & 0 & 0 & 0 & 0 & 0 & 0 & 0 & 0 & 0 & 0 \\
\hline Haliplectus & 2 & $1 \mathrm{~A}$ & 23 & 29 & 35 & 34 & 54 & 55 & 0 & 3 & 0 & 5 & 0 & 0 \\
\hline Leptolaimus & 2 & $1 \mathrm{~A}$ & 0 & 0 & 0 & 0 & 0 & 0 & 0 & 0 & 0 & 0 & 0 & 0 \\
\hline Metachromadora & 3 & $2 \mathrm{~A}$ & 0 & 0 & 0 & 0 & 0 & 0 & 0 & 0 & 0 & 0 & 0 & 0 \\
\hline Metacyatholaimus & 3 & $2 \mathrm{~A}$ & 0 & 0 & 0 & 0 & 0 & 0 & 0 & 0 & 2 & 1 & 0 & 0 \\
\hline Microlaimus & 2 & $2 \mathrm{~A}$ & 0 & 0 & 0 & 0 & 0 & 0 & 0 & 0 & 2 & 0 & 0 & 0 \\
\hline
\end{tabular}




\begin{tabular}{|c|c|c|c|c|c|c|c|c|c|c|c|c|c|c|}
\hline \multirow{4}{*}{$\begin{array}{l}\text { NEMATODE } \\
\text { GENUS }\end{array}$} & \multirow{4}{*}{$\begin{array}{l}\text { c-p } \\
\text { values }\end{array}$} & \multirow{4}{*}{$\begin{array}{l}\text { Feeding } \\
\text { types }\end{array}$} & \multirow{2}{*}{\multicolumn{12}{|c|}{$\begin{array}{l}\text { E1 } \\
\text { Salinity range amongst the sites }\end{array}$}} \\
\hline & & & & & & & & & & & & & & \\
\hline & & & \multicolumn{6}{|c|}{ 0-3NST } & \multicolumn{6}{|c|}{ 3-5NST } \\
\hline & & & $\begin{array}{l}\text { Jun- } \\
17\end{array}$ & $\begin{array}{l}\text { Aug- } \\
17\end{array}$ & $\begin{array}{l}\text { Oct- } \\
17\end{array}$ & $\begin{array}{l}\text { Dec- } \\
17\end{array}$ & $\begin{array}{l}\text { Feb- } \\
18\end{array}$ & $\begin{array}{l}\text { Apr- } \\
18\end{array}$ & $\begin{array}{l}\text { Jun- } \\
17\end{array}$ & $\begin{array}{l}\text { Aug- } \\
17\end{array}$ & $\begin{array}{l}\text { Oct- } \\
17\end{array}$ & $\begin{array}{l}\text { Dec- } \\
17\end{array}$ & $\begin{array}{l}\text { Feb- } \\
18\end{array}$ & $\begin{array}{l}\text { Apr- } \\
18\end{array}$ \\
\hline Monhystera & 2 & 1B & 0 & 0 & 0 & 0 & 0 & 0 & 0 & 0 & 6 & 0 & 0 & 0 \\
\hline Neochomadora & 3 & $2 \mathrm{~A}$ & 0 & 0 & 0 & 0 & 0 & 0 & 0 & 0 & 0 & 0 & 0 & 0 \\
\hline Oncholaimellus & 3 & $2 \mathrm{~B}$ & 0 & 0 & 0 & 0 & 0 & 0 & 0 & 0 & 0 & 0 & 0 & 0 \\
\hline Oxystomina & 4 & $1 \mathrm{~A}$ & 0 & 0 & 6 & 0 & 0 & 0 & 0 & 0 & 0 & 0 & 0 & 0 \\
\hline Paracyatholaimus & 2 & $2 \mathrm{~A}$ & 0 & 0 & 0 & 0 & 0 & 0 & 0 & 0 & 0 & 0 & 0 & 0 \\
\hline Paramonohystera & 4 & 1B & 0 & 4 & 3 & 4 & 13 & 0 & 14 & 4 & 9 & 6 & 8 & 0 \\
\hline Pomponema & 3 & $2 \mathrm{~B}$ & 0 & 0 & 0 & 0 & 0 & 0 & 0 & 0 & 0 & 0 & 0 & 0 \\
\hline Pseudochromadora & 3 & $2 \mathrm{~A}$ & 0 & 0 & 0 & 0 & 0 & 0 & 0 & 0 & 0 & 1 & 0 & 0 \\
\hline Rhabditis & 1 & $1 \mathrm{~A}$ & 1 & 3 & 4 & 8 & 3 & 0 & 0 & 0 & 0 & 0 & 0 & 0 \\
\hline Sabatiera & 2 & 1B & 0 & 0 & 0 & 4 & 1 & 0 & 8 & 3 & 0 & 0 & 0 & 0 \\
\hline Scaptrella & 2 & $2 \mathrm{~B}$ & 0 & 0 & 0 & 0 & 0 & 0 & 0 & 0 & 0 & 0 & 0 & 0 \\
\hline Spirinia & 3 & $2 \mathrm{~A}$ & 0 & 0 & 0 & 0 & 0 & 0 & 0 & 0 & 0 & 0 & 0 & 0 \\
\hline Synonchium & 3 & $2 \mathrm{~B}$ & 0 & 8 & 12 & 2 & 4 & 0 & 6 & 6 & 0 & 0 & 0 & 0 \\
\hline Terschellingia & 3 & 1B & 2 & 5 & 2 & 8 & 4 & 0 & 56 & 56 & 50 & 30 & 52 & 41 \\
\hline Theristus & 2 & 1B & 6 & 3 & 3 & 4 & 0 & 0 & 12 & 10 & 13 & 31 & 25 & 34 \\
\hline Viscocia & 3 & $2 \mathrm{~B}$ & 1 & 3 & 3 & 6 & 5 & 0 & 0 & 5 & 3 & 0 & 2 & 5 \\
\hline Xyala & 3 & $1 \mathrm{~B}$ & 0 & 0 & 0 & 0 & 0 & 0 & 0 & 0 & 0 & 0 & 0 & 0 \\
\hline
\end{tabular}

Table 4. Continued.

\begin{tabular}{|c|c|c|c|c|c|c|c|c|c|c|c|c|c|c|}
\hline \multirow{4}{*}{$\begin{array}{l}\text { NEMATODE } \\
\text { GENUS }\end{array}$} & \multirow{4}{*}{$\begin{array}{l}\text { c-p } \\
\text { values }\end{array}$} & \multirow{4}{*}{$\begin{array}{l}\text { Feeding } \\
\text { types }\end{array}$} & \multirow{2}{*}{\multicolumn{6}{|c|}{$\begin{array}{l}\text { E3 } \\
\text { Salinity range amongst the sites }\end{array}$}} & \multicolumn{6}{|l|}{ E4 } \\
\hline & & & & & & & & & \multirow{2}{*}{\multicolumn{6}{|c|}{ 18-26NST }} \\
\hline & & & \multicolumn{6}{|c|}{$5-18 N S T$} & & & & & & \\
\hline & & & $\begin{array}{l}\text { Jun- } \\
17\end{array}$ & $\begin{array}{l}\text { Aug- } \\
17\end{array}$ & $\begin{array}{l}\text { Oct- } \\
17\end{array}$ & $\begin{array}{l}\text { Dec- } \\
17\end{array}$ & $\begin{array}{l}\text { Feb- } \\
18\end{array}$ & $\begin{array}{l}\text { Apr- } \\
18\end{array}$ & $\begin{array}{l}\text { Jun- } \\
17\end{array}$ & $\begin{array}{l}\text { Aug- } \\
17\end{array}$ & $\begin{array}{l}\text { Oct- } \\
17\end{array}$ & $\begin{array}{l}\text { Dec- } \\
17\end{array}$ & $\begin{array}{l}\text { Feb- } \\
18\end{array}$ & $\begin{array}{l}\text { Apr- } \\
18\end{array}$ \\
\hline Adoncholaimus & 3 & $2 \mathrm{~B}$ & 0 & 1 & 2 & 10 & 11 & 0 & 0 & 6 & 0 & 1 & 2 & 0 \\
\hline Aegialoalaimus & 4 & $1 \mathrm{~A}$ & 0 & 0 & 3 & 0 & 10 & 0 & 0 & 11 & 12 & 6 & 0 & 8 \\
\hline Anoplostoma & 2 & $1 \mathrm{~B}$ & 2 & 0 & 0 & 6 & 0 & 0 & 0 & 9 & 3 & 6 & 4 & 3 \\
\hline Axonolaimus & 2 & $1 \mathrm{~B}$ & 0 & 0 & 0 & 0 & 0 & 0 & 0 & 11 & 0 & 10 & 4 & 4 \\
\hline Batylaiumus & 2 & $1 \mathrm{~B}$ & 10 & 0 & 0 & 11 & 0 & 50 & 0 & 0 & 0 & 0 & 0 & 4 \\
\hline Camacolaimus & 3 & $2 \mathrm{~A}$ & 0 & 0 & 0 & 0 & 0 & 2 & 0 & 0 & 0 & 0 & 0 & 0 \\
\hline Cephalainticoma & 2 & $2 \mathrm{~A}$ & 2 & 0 & 0 & 0 & 0 & 0 & 0 & 0 & 0 & 2 & 0 & 0 \\
\hline Daptonema & 3 & $1 \mathrm{~B}$ & 10 & 0 & 0 & 9 & 5 & 5 & 10 & 0 & 0 & 6 & 12 & 2 \\
\hline Dichromadora & 2 & $2 \mathrm{~A}$ & 3 & 0 & 0 & 0 & 20 & 0 & 12 & 2 & 0 & 3 & 10 & 8 \\
\hline Dolicholaimus & 2 & $2 \mathrm{~B}$ & 4 & 0 & 1 & 0 & 0 & 0 & 0 & 0 & 0 & 2 & 10 & 0 \\
\hline Enoplus & 5 & $2 \mathrm{~B}$ & 6 & 0 & 0 & 0 & 0 & 0 & 0 & 3 & 0 & 0 & 0 & 0 \\
\hline Filoncholaimus & 4 & $2 \mathrm{~B}$ & 6 & 20 & 5 & 0 & 9 & 0 & 2 & 0 & 0 & 0 & 0 & 0 \\
\hline Halalaimus & 4 & $1 \mathrm{~A}$ & 5 & 0 & 0 & 2 & 3 & 0 & 0 & 3 & 0 & 0 & 2 & 0 \\
\hline Haliplectus & 2 & $1 \mathrm{~A}$ & 0 & 0 & 0 & 1 & 0 & 0 & 0 & 0 & 0 & 0 & 0 & 0 \\
\hline Leptolaimus & 2 & $1 \mathrm{~A}$ & 3 & 0 & 1 & 3 & 0 & 0 & 1 & 5 & 3 & 3 & 0 & 0 \\
\hline Metachromadora & 3 & $2 \mathrm{~A}$ & 0 & 8 & 0 & 0 & 0 & 5 & 5 & 7 & 10 & 4 & 8 & 0 \\
\hline Metacyatholaimus & 3 & $2 \mathrm{~A}$ & 0 & 0 & 0 & 0 & 0 & 0 & 0 & 0 & 0 & 0 & 0 & 0 \\
\hline Microlaimus & 2 & $2 \mathrm{~A}$ & 3 & 2 & 1 & 1 & 3 & 0 & 1 & 6 & 5 & 7 & 2 & 0 \\
\hline Monhystera & 2 & $1 \mathrm{~B}$ & 0 & 2 & 2 & 0 & 0 & 0 & 5 & 2 & 0 & 7 & 3 & 0 \\
\hline Neochomadora & 3 & $2 \mathrm{~A}$ & 0 & 3 & 7 & 6 & 9 & 4 & 0 & 0 & 0 & 13 & 0 & 0 \\
\hline Oncholaimellus & 3 & $2 \mathrm{~B}$ & 0 & 1 & 2 & 1 & 0 & 0 & 0 & 2 & 0 & 0 & 0 & 0 \\
\hline Oxystomina & 4 & $1 \mathrm{~A}$ & 0 & 20 & 10 & 9 & 0 & 8 & 3 & 0 & 0 & 0 & 0 & 0 \\
\hline Paracyatholaimus & 2 & $2 \mathrm{~A}$ & 0 & 0 & 0 & 0 & 2 & 0 & 4 & 10 & 0 & 0 & 13 & 0 \\
\hline Paramonohystera & 4 & $1 \mathrm{~B}$ & 1 & 19 & 12 & 5 & 2 & 3 & 2 & 1 & 0 & 3 & 4 & 1 \\
\hline Pomponema & 3 & $2 \mathrm{~B}$ & 0 & 0 & 3 & 2 & 5 & 0 & 6 & 0 & 0 & 2 & 4 & 32 \\
\hline Pseudochromadora & 3 & $2 \mathrm{~A}$ & 4 & 0 & 10 & 7 & 5 & 2 & 2 & 1 & 12 & 0 & 0 & 0 \\
\hline Rhabditis & 1 & $1 \mathrm{~A}$ & 0 & 0 & 0 & 3 & 0 & 5 & 6 & 0 & 2 & 0 & 0 & 4 \\
\hline Sabatiera & 2 & 1B & 5 & 12 & 14 & 20 & 0 & 0 & 10 & 0 & 5 & 3 & 0 & 19 \\
\hline Scaptrella & 2 & $2 \mathrm{~B}$ & 0 & 0 & 0 & 0 & 0 & 0 & 3 & 4 & 6 & 5 & 0 & 0 \\
\hline Spirinia & 3 & $2 \mathrm{~A}$ & 0 & 0 & 0 & 0 & 0 & 0 & 3 & 1 & 0 & 2 & 3 & 5 \\
\hline Synonchium & 3 & $2 \mathrm{~B}$ & 0 & 0 & 0 & 0 & 0 & 0 & 0 & 0 & 0 & 0 & 0 & 0 \\
\hline Terschellingia & 3 & $1 \mathrm{~B}$ & 0 & 4 & 9 & 0 & 0 & 0 & 10 & 6 & 10 & 10 & 8 & 0 \\
\hline Theristus & 2 & $1 \mathrm{~B}$ & 36 & 3 & 5 & 4 & 0 & 1 & 0 & 5 & 10 & 0 & 0 & 1 \\
\hline Viscocia & 3 & $2 \mathrm{~B}$ & 0 & 5 & 12 & 0 & 16 & 15 & 16 & 3 & 12 & 6 & 11 & 9 \\
\hline Xyala & 3 & $1 \mathrm{~B}$ & 0 & 0 & 1 & 0 & 0 & 0 & 0 & 2 & 10 & 1 & 0 & 0 \\
\hline
\end{tabular}

A K-dominance curve (Figure 3) further indicated that at cumulative dominance of $40 \%$ a single genus (Haliplectus) dominated the nematodes communities at site E1. The dominance of a single genus (Terschellingia) at a cumulative dominance 
above $40 \%$ was also observed at site E2.

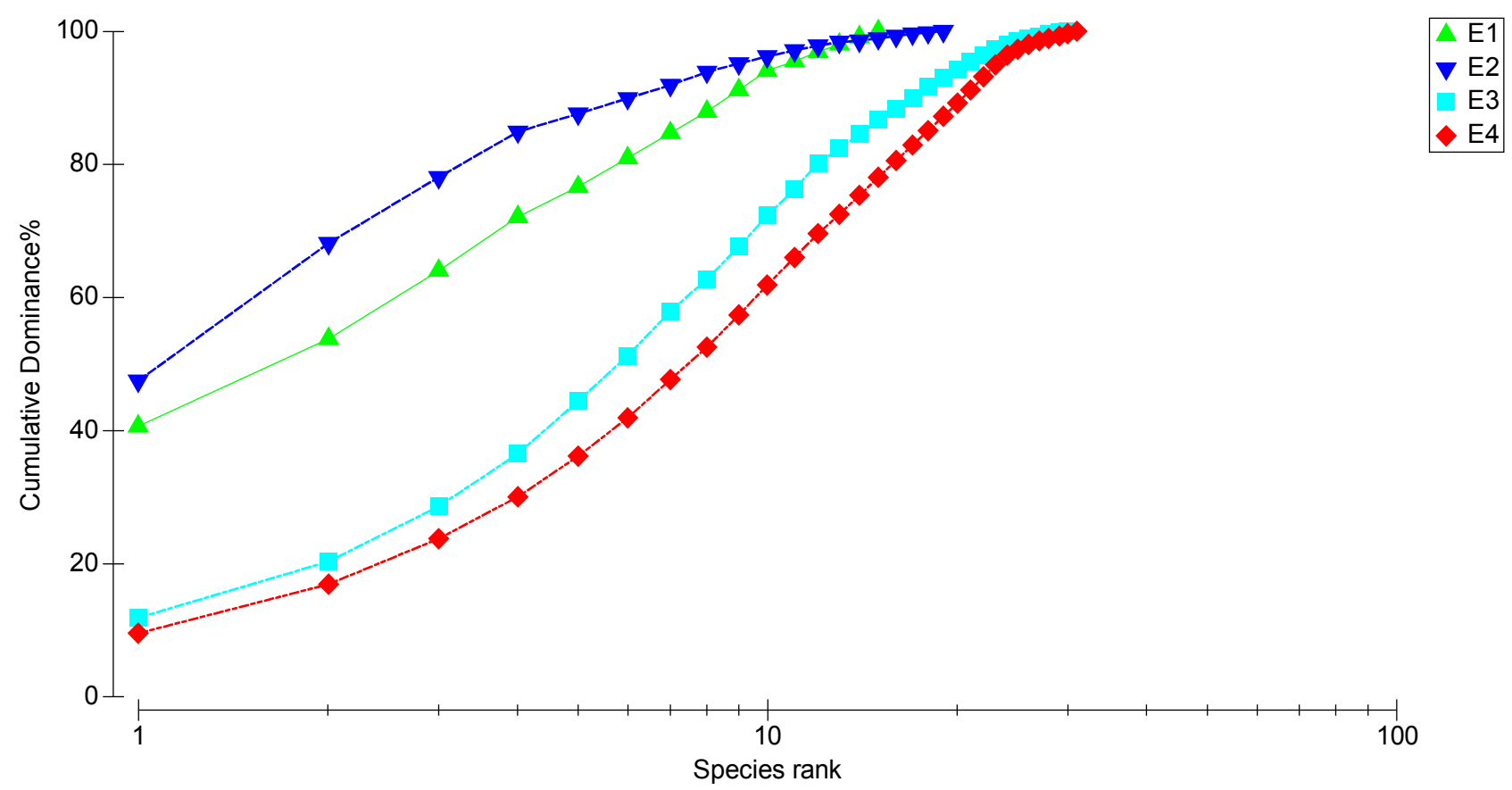

Figure 3. Ranked species K-dominance curves for the free-living nematode genera identified at the Incomati River Estuary.

\subsubsection{Nematode Feeding Types}

All four nematode feeding types were found, and their trophic diversity percentage were calculated for their dominance between the sites (Figure 4). The Trophic Diversity Index percentage indicated that throughout the study, nematodes feeding type 1B (non-selective deposit feeders) were dominant in all sites sampled. The highest mean percentage contributions of feeding type $1 \mathrm{~B}$ was observed at site E2 with $88.9 \%$. Sites E2 (Euhaline Zone) and E3 (Mesohaline Zone) had similar percentage contribution of feeding type $1 \mathrm{~B}$. The mean percentage of the feeding types indicated that feeding type $1 \mathrm{~B}$ was the dominant group, followed by feeding type 2B. A two-way ANONISM permutation test indicated that significant difference exists between sites $(\mathrm{Rho}=0.221 ; \mathrm{p}=0.043)$, and between month sampled $(\mathrm{Rho}=0.688 ; \mathrm{p}=0.001)$.

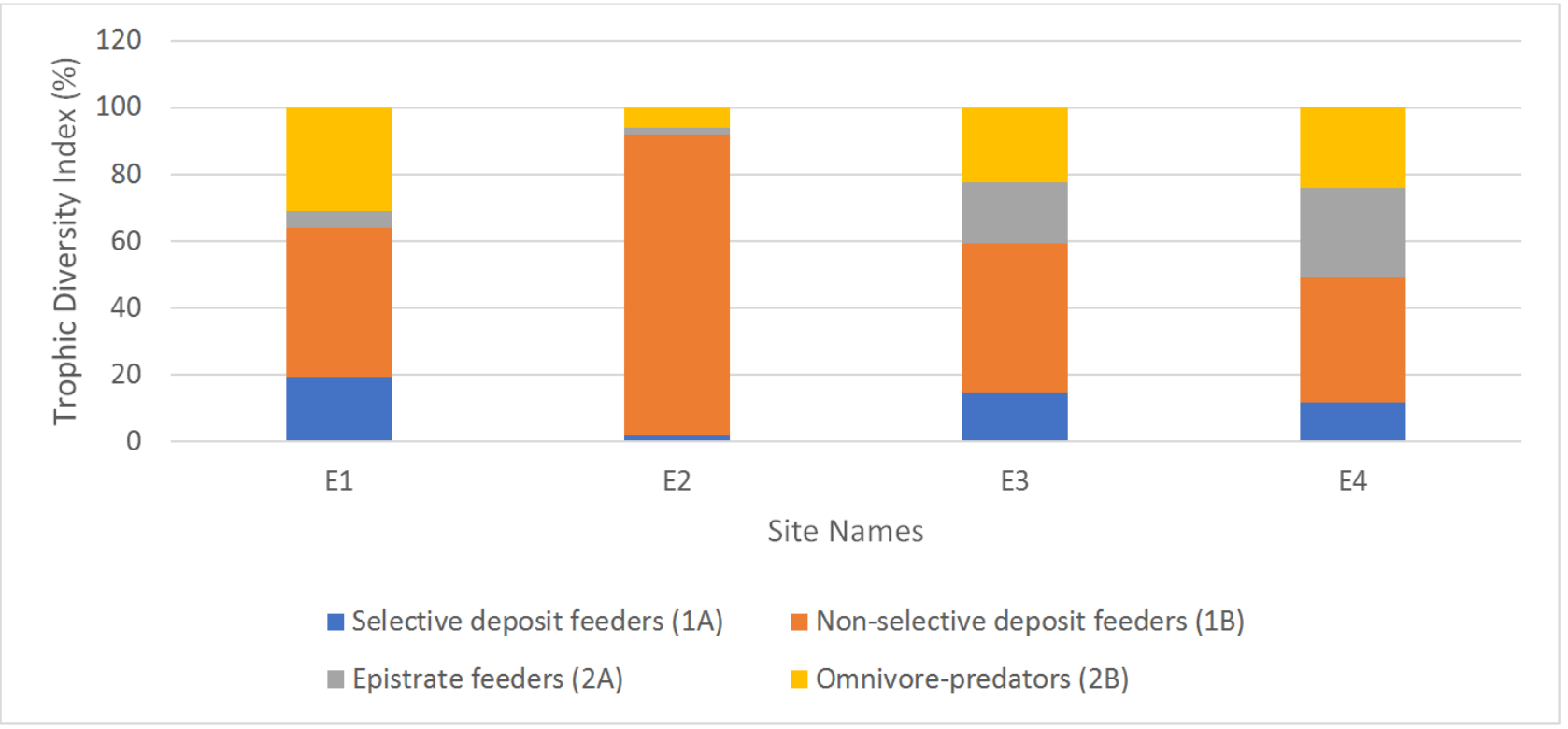

Figure 4. Trophic Diversity Index percentage of nematode feeding types in the Incomati River Estuary.

\subsubsection{Relationships Between Free-living Nematodes and Environmental Factors}

The first two axes of the RDA accounted for $92.51 \%$ of the variation in free-living nematodes and environmental factors (figure 5). The first axes accounted for $68.94 \%$ and the second axes accounted $23.57 \%$ of the variance in the data. 


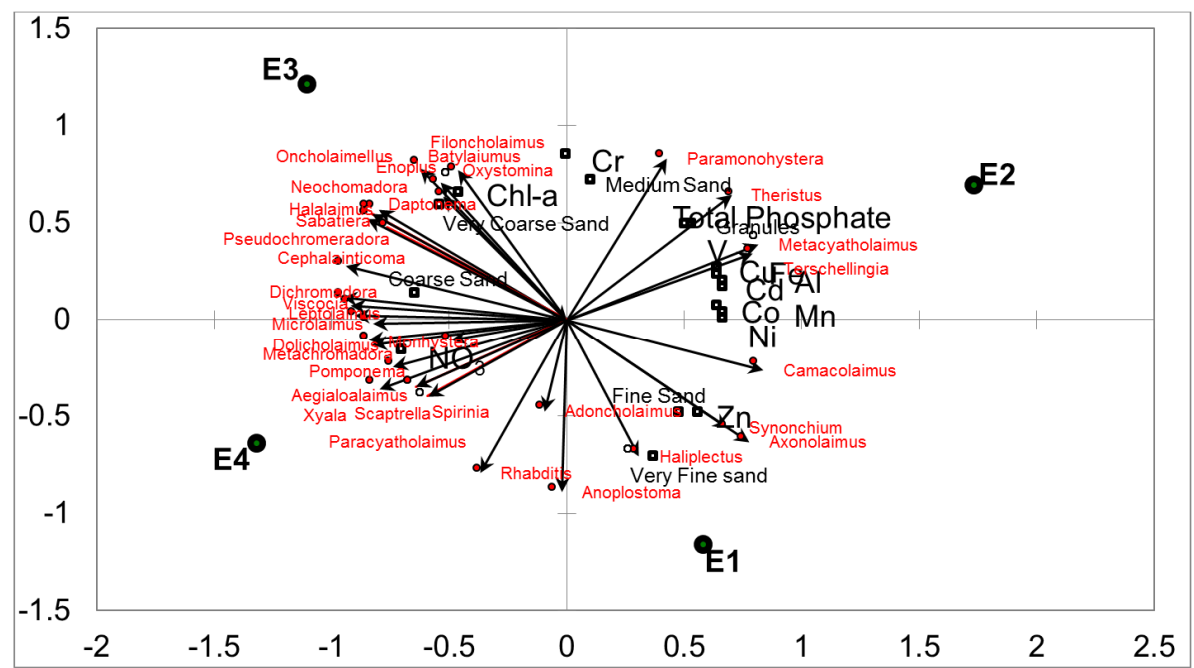

Figure 5. RDA tri-plot illustrating the relationship between nematodes diversity and environmental factors found in the Incomati River Estuary.

A spearman analysis showed that there was a significant correlation $(\mathrm{Rho}=0.381 ; \mathrm{p}=0.001)$ between environmental factors and free-living nematodes. A relationship between environmental factors such as Coarse sand, Very Coarse Sand, Chlorophyll- $a$, Nitrates and free-living nematodes was found at sites E3 and E4. Another relationship between heavy metals such as Copper, Iron, Vanadium, Manganese, Cadmium, Aluminium, Nickel and Cobalt, Total phosphate with free-living nematodes such as Paramonohystera, Theristus, Terschellingia and Metacytholaimus were found as site E2. Fine sand, very fine sand and Zinc were found to relate with free-living nematodes such as Camacolaimus, Adoncholaimus, Synonchium, Axonolaimus and Haliplectus at site E1. A marginal test in the DistLM procedure (Table 5) confirmed that heavy metals (Cobalt, Manganese, Nickel, Vanadium and Aluminium), Nutrients (Total Phosphate and Nitrates), and sediment particle size (Granules, Very Coarse Sand, Coarse, Very Coarse Sand, Medium Coarse Sand, Fine Medium Sad and Fine sand) were strongly associated with free-living nematodes composition in the Estuary when considered independently.

Table 5. Relationship between environmental variables and free-living nematodes based on AIC DISTLIM. Marginal test considers the importance of each variable in the absence of the other variables. Sequential tests consider the importance of variables in conjunction with the other variables starting with the variable with the variable explaining the greatest variance.

\begin{tabular}{llll}
\hline Variables & SS & Pseudo-F & P values \\
\hline Marginal test & & & \\
Cadmium & 2697.4 & 1.2451 & 0.278 \\
Chromium & 2251.9 & 1.0298 & 0.426 \\
Copper & 3744 & 1.7669 & 0.085 \\
Zinc & 3001 & 1.3941 & 0.193 \\
Chlorophyll-a & 3898.4 & 1.846 & 0.065 \\
Cobalt & 6000.2 & 2.9758 & $0.007^{*}$ \\
Iron & 4366.5 & 2.0887 & 0.055 \\
Manganese & 6324.8 & 3.1599 & $0.006^{*}$ \\
Nickel & 6227.7 & 3.1046 & $0.008^{*}$ \\
Vanadium & 5048.8 & 2.4514 & $0.023^{*}$ \\
Aluminium & 6073.4 & 3.0171 & $0.011^{*}$ \\
Total Phosphate & 4505.5 & 2.1617 & $0.034^{*}$ \\
Nitrate & 11937 & 6.837 & $0.001^{*}$ \\
\hline
\end{tabular}

\begin{tabular}{|c|c|c|c|}
\hline Variables & SS & Pseudo-F & $P$ values \\
\hline Granules & 8815.4 & 4.6683 & $0.001 *$ \\
\hline Very Coarse Sand & 13534 & 8.0855 & $0.001 *$ \\
\hline Coarse Very Coarse Sand & 14517 & 8.9108 & $0.001 *$ \\
\hline Medium Coarse Sand & 9528.9 & 5.1343 & $0.001 *$ \\
\hline Fine Medium Sand & 14764 & 9.1252 & $0.001 *$ \\
\hline Fine Sand & 10970 & 6.1272 & $0.001 *$ \\
\hline \multicolumn{4}{|l|}{ Sequential test } \\
\hline Fine Medium Sand & 14764 & 9.1252 & $0.001 *$ \\
\hline Medium Coarse Sand & 9321.6 & 7.4506 & $0.001 *$ \\
\hline Granules & 4002.3 & 3.5941 & $0.001 *$ \\
\hline Very Coarse Sand & $2.868^{-11}$ & 0 & 1 \\
\hline \multicolumn{4}{|l|}{ Overall best solution } \\
\hline AIC & RSS & \multicolumn{2}{|c|}{ Number of Variables } \\
\hline 0.55775 & 22271 & \multicolumn{2}{|l|}{4} \\
\hline
\end{tabular}

*indicate significant.

The sequential test in the DistLM analysis also showed that sediment particle size such as Granules, Medium Coarse Sand, Fine Medium Sand were the best subset of explanatory environmental factors to account for the differences in freeliving nematodes community structure.

\subsubsection{Maturity Index}

A Maturity Index (MI) which is a potential indicator of nematode assemblage under stress were calculated for the four sites sampled (Table 6).

Table 6. Monthly and Mean Maturity Index values from June 2017 to April 2018 and the Maturity Threshold proposed by Moreno et al. 2011.

\begin{tabular}{lllll}
\hline Site Names & E1 & E2 & E3 & E4 \\
\hline June 2017 & 2.40 & 2.85 & 2.81 & 2.67 \\
August 2017 & 1.71 & 1.70 & 2.50 & 2.80 \\
October 2017 & 2.60 & 2.75 & 2.84 & 2.46 \\
December 2017 & 2.63 & 2.53 & 2.75 & 2.62 \\
February 2018 & 2.80 & 2.50 & 3.07 & 2.88 \\
April 2018 & 2.53 & 2.00 & 2.08 & 2.54 \\
Mean & 2.44 & 2.38 & 2.67 & 2.66 \\
\hline \multicolumn{5}{c}{ Moderate } \\
\hline Maturity Index threshold (Moreno et al. 2011) \\
\hline High \\
\hline$>2.8$ & Good & Poor & Bad \\
\hline
\end{tabular}


The results of the MI varied monthly which indicated that there was a change in nematodes diversity and density in the estuary. The lowest MI values at sites E1 (Oligohaline Zone) and E2 (Euhaline Zone) were found in August 2017 with MI values of 1.71 and 1.72 , while the highest MI values were found in February 2019 and June 2017 with MI values of 2.8 and 2.85 respectively. The mean MI values for sites E1 situated in Oligohaline Zone and E2 situated in Euhaline Zone were 2.44 and 2.38 respectively. At sites E3 (Mesohaline Zone) and E4 (Oligohaline Zone) the highest MI values were observed in February 2018 with a MI values of 3.07 and 2.88, while the lowest was observed in April 2018 and October 2017 with MI values of 2.08 and 2.46 respectively. The mean MI values for sites E3 situated in Mesohaline Zone and E4 situated in Polyhaline Zone were 2.67 and 2.66 respectively.

\section{Discussions}

Sites E1 and E2 were mostly characterised by fine sand and granules respectively, while both sites E3 and E4 were characterised by very coarse particle size which were believed to be attributed to tidal action that washes the sand from small particles. There was no significant difference ( $p>0.05)$ of sediment particles size between the sites sampled which indicated that sediments composition in terms of particle size was not very heterogeneous. A higher concentration of heavy metals such as Nickel, Cobalt, Chromium, Copper, Iron, Manganese, Cadmium, Vanadium, Zinc and Aluminium found at sites E1 and E2 were attributed to anthropogenic activities along the Incomati River which discharges in to the Incomati River Estuary in Mozambique (Table 1). Heavy metals have been found to be introduced in the marine environment through natural and anthropogenic process [55-56]. These anthropogenic activities in the study include mining, agriculture, and industries in South Africa and Mozambique [40]. The concentration of heavy metals in the study were found to change spatially but not temporal, which indicated that within the Estuary different sites received different amount of pollution concentration. The sources of the higher concentration of total phosphate found at sites E1 and E2 and nitrates found at sites E3 and E4 were believed to be due to agricultural activities. A positive correlation (Figure 2) between heavy metals and sediments particle size such as granule and fine sand indicated that heavy metals were distributed base on sediment particles size. In a similar study fine sediment were found to contribute to the distribution of higher metal concentration by giving enough specific areas for metal attachments [57]. Free-living nematodes were found to be the dominate meiofauna in the study, and their density and diversity decreased towards the Oligohaline Zone (Site E1). Several authors also found that nematodes decrease towards the Oligohaline Zone and they were dominant meiofauna in an estuarine environment [3, 58-62]. Nematode feeding type $1 \mathrm{~B}$ (non-selective deposit feeders) were dominant at all the sites but mostly at site E2. The dominance of this feeding type $1 \mathrm{~B}$ explained the food availability of nematodes at the sites [50, 63-64]. A positive correlation of heavy metals such as Copper, Iron, Vanadium, Manganese, Cadmium, Aluminium, Nickel, Cobalt, Total Phosphate with free-living nematode such as Paramonohystera, Theristus, Terschellingia and Metacytholaimus at site E2 (Euhaline Zone); and another positive correlation of fine sand, very fine sand and Zinc with free-living nematodes such as Camacolaimus, Adoncholaimus, Synonchium, Axonolaimus and Haliplectus at site E1 (Oligohaline Zone) indicated that these genera are tolerant to pollution $[17,34,65-66]$. The marginal test in the DistLM further confirmed that heavy metals, nutrients and sediment particle size were strongly associated with freeliving nematodes composition when considered independently, while the sequential test DistLM indicated that sediment particle size such as granules, fine medium sand and medium coarse sand were the best subset accountable for the structuring of free-living nematode. Within an area of uniform salinity; grain size sediments are the dominant factor in determining the composition of nematode communities [67-69]. Several authors found that nematodes composition is mostly structured by sediment grain size [32, 70-72]. Sites E2 and E1 which were under stress were mostly dominated by single genus (Figure 3 ). The Maturity Index (Table 5) also indicated that site E2 (Euhaline Zone) was in a poor condition while site E1 was in a moderate condition [73]. The poor condition at site E2 (Euhaline Zone) was attributed to the higher concentration of heavy metals and total phosphates. The lower values of MI indicate disturbed/polluted environments [73]. Sites E1 and E2 had average MI of 2.44 and 2.38 respectively. Nematode genera such as Terschellingia and Theristus that are tolerant to pollution were found at sites E1 and E2. Similar observations were also made in other studies $[18,33]$.

\section{Conclusion}

Free-living nematodes such as Terschellingia and Theristus were dominant genera at site E2 (Euhaline Zone) and site E1 (Oligohaline Zone). The two sites were found to be polluted. The two genera (Terschellingia and Theristus) were found to be good indicators of pollution associated with heavy metals and nutrients in Incomati River Estuary. A Maturity Index threshold used indicated that the Incomati River Estuary pollution status was poor at site E2 (Euhaline Zone), moderate at site E1 (Oligohaline Zone) and good at both sites E3 (Mesohaline Zone) and E4 (Polyhaline Zone). The source of pollution in the Incomati River Estuary was believed to be anthropogenic activities from upper catchments.

\section{Recommendation}

Further studies confirming the findings of this study must be done in the Incomati River Estuary and other regions on the African Coast to understand free-living nematodes in relation to pollution and use the results to update in our 
monitoring strategies.

\section{Acknowledgements}

We would like to thank the Inkomati-Usuthu Catchment Management Agency which is the first CMA to be establish in South Africa for their funding for this study.

\section{References}

[1] Kennish, M. J. 2002. Environmental threats and environmental futures of estuaries. Environmental Conservation. 29: 78-107.

[2] Dolbeth, M., Pardal, M. A., Lillebø, A. I., Azeiteiro, U. M. \& Marques, J. C. 2003. Short and long-term effects of eutrophication on the secondary production of an intertidal macrobenthic community. Marine Biology. 143: 1229-1238.

[3] Paerl, W. H. 2006. Assessing and managing nutrient-enhanced eutrophication in estuarine and coastal waters: Interactive effects of human and climatic perturbations. Ecological Engineering. 26: 40-54.

[4] Lillebø, A. I., Neto, J. M., Martins, I., Verdelhos, T., Leston, S., Cardoso, P. G., Ferreira, S. M., Marques, J. C. \& Pardal, M. A. 2005. Management of a shallow temperate estuary to control eutrophication: the effect of hydrodynamics on the system's nutrient loading. Estuarine, Coastal and Shelf Science. 65: 697-707.

[5] Sengo, D. J. 2003. Effects of water management in Incomati River Basin into estuarine system: a downstream perspective of socio-economic demands from the estuarine services. MSc Thesis Water Management. UNESCO-IHE, Delft.

[6] Kennedy, A. D. \& Jacoby, C. A. 1999. Biological indicators of marine environmental health: meiofauna e a neglected benthic component? Environmental Monitoring Assessment. 54: 4768.

[7] Schratzberger, M., Gee, J. M., Rees, H. L., Boyd, S. E. \& Wall, C. M. 2000. The structure and taxonomic composition of sublittoral meiofauna assemblages as an indicator of the status of marine environments. Journal of the Marine Biology Association of the United Kingdom. 80: 969-980.

[8] Schratzberger, M. 2012. On the relevance of meiobenthic research for policymakers. Marine Pollution Bulleting. 64: 2639-2644.

[9] Alves, A. S., Adãob, H., Ferrero, T. J., Marques, J. C., Costad, M. J. \& Patrício, J. 2013. Benthic meiofauna as indicator of ecological changes in estuarine ecosystems: The use of nematodes in ecological quality assessment. Ecological Indicators. 24: 462-475.

[10] Vanaverbeke, J., Gheskiere, T. \& Vincx, M. 2000. The meiobenthos of Subtidal Sandbanks on the Belgian Continental Shelf. Estuarine, Coastal and Shelf Science. 51: 637-649.

[11] Yeates, G. W., Percival, H. J. \& Parshotam, A. 2003. Soil nematode responses to year-to-year variation of low levels of heavy metals. Australian Journal of Soil Research. 41: 613625 .

[12] McLachlan, A. \& Brown, A. C. 2006. The ecology of sandy shores. 2nd Ed. Amsterdam: Elsevier Science.

[13] Zhang, X. K., Li, Q., Wang, S. B., Jiang, Y. \& Liang, W. 2006. Effect of zinc addition to soil on nematode community structure. Bulletin of Environmental Contaminants and Toxicology. 76: 589-594.

[14] Mirto, S., La Rosa, T., Gambi, C., Danovaro, R. \& Mazzola, A. 2002. Nematode community response to fish-farm impact in the western Mediterranean. Environmental Pollution. 116: 203-214.

[15] Fraschetti, S., Gambi, C., Giangrande, A., Musco, L. \& Terlizzi, A. 2006. Structural and functional response of meiofauna rocky assemblages to sewage pollution. Marine Pollution Bulletin. 52: 540-548.

[16] Moreno, M., Albertelli, G. \& Fabiano, M. 2009. Nematode response to metal, PAHs and organic enrichment in tourist marinas of the Mediterranean Sea. Marine Pollution Bulletin. 58: 1192-1201.

[17] Vezzulli, L., Moreno, M., Marin, V., Pezzati, E. \& Bartoli, M. 2008. Organic waste impact of capture-based Atlantic bluefin tuna aquaculture at an exposed site in the Mediterranean Sea. Estuarine, Coastal and Shelf Science. 78: 369-384.

[18] Gyedu-Ababio, T. K. \& Baird, D. 2006. Response of meiofauna and nematode communities to increased levels of contaminants in a laboratory microcosm experiment. Ecotoxicology \& Environmental Safety. 63: 443-450.

[19] Heip, C., Vincx, M. \& Vranken, G. 1985. The ecology of marine nematodes. Oceanography and Marine. 23: 399-489.

[20] Moens, T., Bouillon, S. \& Gallucci, F. 2005. Dual stable isotope abundances unravel trophic position of estuarine nematodes. Journal of Marine Biology Association of the United Kingdom. 85: 1401-1407.

[21] Austen, M. C. \& Widdicombe, S. 2006. Comparison of the response of meiobenthos and macrobenthos to disturbance and organic enrichment. Journal of Experimental Marine Biology and Ecology. 330: 96-104.

[22] Heip, C., Basford, D., Craeymeersch, J. A., Dewarumez, J. M., Dorjes, J., de Wilde, P., Duineveld, G., Eleftheriou, A., Herman, P. M. J., Niermann, U., Kingston, P., Kunitzer, A., Rachor, E., Rumohr, H., Soetaert, K. \& Soltwedel, T. 1992. Trends in biomass, density and diversity of North Sea macrofauna. ICES Journal of Marine Science. 49: 13-22.

[23] Zhang, Z. N., Zhou, H., Yu, Z. S. \& Han, J. 2001. Abundance and biomass of the benthic meiofauna in the northern softbottom of the Jiaozhou Bay. Oceanologia of Limnologia Sinica. 32: 139-147.

[24] Guo, Y. Q., Zhang, Z. N. \& Mu, F. H. 2002. Large-Scale Patterns of meiofaunal abundance in the Bohai Sea. Acta Ecologica Sinica. 22: 1463-1469.

[25] Liu, X. S., Zhang, Z. N. \& Huang, Y. 2005. Abundance and biomass of meiobenthos in the spawning ground of anchovy in the southern Huanghai Sea, China. Acta Oceanologica Sinica. 24: 94-104.

[26] Liu, X., Zhang, Z. \& Huang, Y. 2007: Sublittoral meiofauna with particular reference to nematodes in the southern Yellow Sea, China. Estuarine, Coastal and Shelf Science. 71: 616628 . 
[27] Zhang, Z. N. \& Zhou, H. 2004. Some progress on the study of meiofauna. Periodical of Ocean University of China. 34: 799806.

[28] Hua, E., Zhang, Z. N. \& Zhang, Y. 2006. Meiofauna distributions at the oxygen minimum zone in Changjiang River Estuary waters. Acta Oceanologica Sinica. 25: 120-134.

[29] McLachlan, A. D. 1977. Analysis of Periodic Patterns in Amino Acid Sequences: Collagen. Biopolymers. 16: 12711297.

[30] Furstenberg, J. P. \& Vincx, M. 1988. Three new species of Chromadoropsis species (Nematoda, Desmodoridae) from Southern Africa and the North Sea. South African Journal of Zoology. 23: 215-223.

[31] Gyedu-Ababio, T. K., Furstenberg, J. P., Baird, D. \& Vanreusel, A. 1999. Nematodes as indicators of pollution: a case study from the Swartkops River System, South Africa. Hydrobiologia. 397: 155-169.

[32] Gyedu-Ababio, T. K. 2011. Pollution status of two river estuaries in the Eastern Cape, South Africa, Based on Benthic Meiofauna Analyses. Journal of Water Resource and Protection. 3: 473-486.

[33] Tietjen, J. H. 1980. Microbial-meiofaunal interrelationships: a review. Microbiology. 335-338.

[34] Bongers, T., Alkemade, R. \& Yeates, G. W. 1991. Interpretation of disturbance-induced maturity decrease in marine nematode assemblages by means of Maturity Index. Marine Ecological Progress Series. 76: 135-142.

[35] Essink, K. \& Keidel, H. 1998. Changes in estuarine nematode communities following a decrease of organic pollution. Aquatic Ecology. 32: 195-202.

[36] Moreno, M., Ferrero, T. J., Gallizia, I., Vezzulli, L., Albertelli, G. \& Fabiano, M. 2008. An assessment of the spatial heterogeneity of environmental disturbance within an enclosed harbour through the analysis of meiofauna and nematode assemblages. Estuarine, Coastal and Shelf Science. 77: 565-576.

[37] Semprucci, F., Moreno, M., Sbrocca, S., Rocchi, M., Albertelli, G. \& Balsamo, M. 2013. The nematode assemblage as a tool for the assessment of marine ecological quality status: a case-study in the Central Adriatic Sea. Marine Science. 14: 48-57.

[38] Ürkmez, D., Sezgin, M. \& Bat, L. 2014. Use of nematode maturity index for the determination of ecological quality status: a case study from the Black Sea. Journal of Black Sea/Mediterranean Environment. 20: 96-107.

[39] Sengo, D., Kachaphila, A., van de Zaag, P., Mul, M. \& Nkomo, S. 2005. Valuing environmental water pulses into the Incomati estuary: Key to achieving equitable and sustainable utilization of transboundary waters.

[40] Hoguane, A. M. 2002. Salt intrusion in Incomati river. Proceedings of the II-national conference on integrated coastal zone management. Proceedings of the II national conference on Coastal Zone Research. Maputo, 27-29 September 2000. CDS-ZC/MICOA, SECAM/UEM, 127 p.

[41] Parker, J. G. 1983. A comparison of methods used for the measurement of organic matter in sediments. Chemistry and Ecology. 1: 201-210.
[42] Lorenzen, C. \& Jeffrey, J. 1980. Determination of chlorophyll in seawater. UNESCO Technical Papers in Marine Sciences. 35: 1-20.

[43] Bate, G. C. \& Heelas, B. V. 1975. Studies on the nitrate nutrition of two indigenous Rhodesian grasses. Journal of applied Ecology. 12: 941-952.

[44] Olsen, S. R. \& Dean, L. A. 1965. Phosphorus. In: Black, C. A (eds). Methods of Soil Analysis, American Society of Agronomy, Madison, USA. pp 1035-1058.

[45] Anderson, R. O. 1959. A modified flotation technique for sorting bottom fauna samples. Limnology and Oceanography. 4: $223-225$.

[46] Heip, C., Smol, N. \& Hautekiet, W. 1974. A rapid method of extracting meiobenthic nematodes and copepods from mud and detritus. Marine Biology. 23: 399-489.

[47] Esteves, A. M. \& Da Silva, V. M. A. P. 1998. The behaviour of sugar flotation technique in meiofauna extraction from different sand types. Tropical Ecology. 39: 283-284.

[48] Giere, O. 1993. Meiobenthology: The microscopic fauna in aquatic sediments. New York: Springer-Verlag.

[49] Warwick, R. M., Platt, H. M. \& Somerfield, P. J. 1998. Freeliving marine nematodes. Part III. British Monhysterida. Synopses of the British Fauna (New Series). Vol 53. Field Studies Council, Shrewsbury, UK. 296 pp.

[50] Wieser, W. 1953. The relationship between oral cavity shape, nutrition meadow and 1000 occurrences in free-living marine nematodes. Archive for Zoology. 4: 439-484.

[51] Legendre, P. \& Anderson, M. J. 1999. Distance-based redundancy analysis: testing multispecies responses in multifactorial ecological experiments. Ecol. Monography. 69: $1-24$.

[52] McArdle, B. H. \& Anderson, M. J. 2001. Fitting multivariate models to community data: A comment on distance-based redundancy analysis. Ecology. 82: 290-29.

[53] Burnham, K. P. \& Anderson, D. R. 2004. Multimodel inference: understanding AIC and BIC in model selection. Society of Method Res. 33: 261-304.

[54] Clarke, K. R. \& Gorley, R. N. 2006. PRIMER v6: User Manual Tutorial. PRIMER-E Ltd. United Kingdom: Plymouth.

[55] Garcia-Montelongo, F., Díaz, C., Galindo, L., Larrechi, M. S. \& Rius, X. 1994. Heavy metals in three fish species from the coastal waters of Santa Cruz de Tenerife (Canary Islands). Scientia Marina. 58: 179-83.

[56] Jordão. C. P., de G Pereira, M. \& Pereira, J. L. 2002. Metal Contamination of River Waters and Sediments from Effluents of Kaolin Processing in Brazil. Water, Air and Soil pollution. 140: $119-138$

[57] Cox, M. E. \& Preda, M. 2005. Trace Metal Distribution Within Marine and Estuarine Sediments of Western Moreton Bay, Queensland, Australia: Relation to Land Use and Setting. Geographical Research. 43: 173-193.

[58] Soetaert, K., Vincx, M., Wittoeck, J., Tulkens, M. \& Van Gansbeke, D. 1994. Spatial patterns of Westerschelde meiobenthos. Estuarine, Coastal and Shelf Science. 39: 367388 . 
[59] Udalov, A. A., Mokievskii, V. O. \& Chertoprud, E. S. 2005. Influence of the salinity gradient on the distribution of meiobenthos in the Chernaya river estuary. Oceanology. 45: 680-688.

[60] Renaud-Debyser, R. J. \& Salvat, B. 1963. Eléments de prospérité des biotopes des sédiments meubles intertidaux et écologie de leurs populations en microfauna et macrofauna. Vie et Milieu. 14: 463-550.

[61] Gray, J. S. \& Rieger, R. 1971. A quantitative study of the meiofauna of an exposed sandy beach, at Robin Hoods Bay, Yorkshire. Journal of the Marine Biology Association of the United Kingdom. 51: 1-19.

[62] Patrício, J., Neto, J. M., Teixeira, H., Salas, F. \& Marques, J. C. 2009. The robustness of ecological indicators to detect long-term changes in the macrobenthos of estuarine systems. Marine Environmental Research. 68: 25-36.

[63] Chinnadurai, G. \& Fernando, O. J. 2007. Meiofauna of mangroves of the southeast coast of India with special reference to the free-living marine nematode assemblage. Estuarine Coastal and Shelf Science. 72: 329-336.

[64] Shabdin, M. L. \& Othman, B. H. R. 2008. Horizontal distribution of intertidal nematode from Sabah, Malaysia. Journal of Tropical Biology and Conservation. 4: 39-53.

[65] Lampadariou, N., Austen, M. C., Robertson, N. \& Vlachonis, G. 1997. Analysis of meiobenthic community structure in relation to pollution and disturbance in Iraklion Harbour, Greece. Vie Milieu. 47: 9-24.

[66] Liu, X., Xu, M., Hua, E. \& Zhang, Z. 2016. Biodiversity of free-living nematodes in the southern Yellow Sea, China. Journal of Ocean University of China. 15: 1-10.

[67] Wieser, W. 1960. Benthic studies in Buzzards Bay. Part II. The Meiofauna. Limnology and Oceanography. 5: 121-137.

[68] Tietjen, J. H. 1977. Population distribution and structure of the free-living nematodes of Long Island Sound. Marine Biology. 43: 123-136.

[69] Ward, A. R. 1975. Studies on the sublittoral free-living nematodes of Liverpool Bay. Part II: Influence of sediment composition on the distribution of marine nematodes. Marine Biology. 30: 217-225.

[70] De Beer, J. D., Dryer, J. \& Loubser, C. 2005. Environmental issues and risks. In: Loubser, C. P. ed. Environmental Education, Some South African Perspectives. Pretoria: Van Schaik Publishers.

[71] Vanaverbeke, J., Merckx, B., Degraer, S. \& Vincx, M. 2011. Sediment-related distribution patterns of nematodes and macrofauna: two sides of the benthic coin? Marine Environmental Research. 71: 31-40.

[72] Fonseca, V. G., Carvallo, G. R., Quince, C., Johnson, H. F., Neill, S. P., Lambshead, J. D., Thomas, W. K., Power, D. M. \& Creer, S. 2014. Metagenetic analysis of patterns of distribution and diversity of marine meiobenthic eukaryotes. Global Ecology and Biogeography. 23: 1293-1302.

[73] Moreno, M., Semprucci, F., Vezzulli, L., Balsamo, M., Fabiano, M. \& Albertelli, G. 2001. The use of nematodes in assessing ecological quality status in the Mediterranean coastal ecosystems. Ecological Indicator. 11: 328-336. 